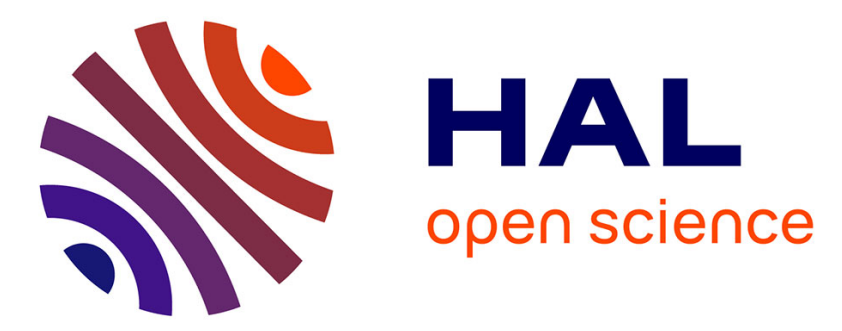

\title{
Discrimination between different water bodies from a multilayered aquifer (Kaluvelly watershed, India): Trace element signature
}

\author{
Nathalie Gassama, Haino Uwe Kasper, Aline Dia, Constantin Cocirta, \\ Martine Bouhnik-Le Coz
}

\section{To cite this version:}

Nathalie Gassama, Haino Uwe Kasper, Aline Dia, Constantin Cocirta, Martine Bouhnik-Le Coz. Discrimination between different water bodies from a multilayered aquifer (Kaluvelly watershed, India): Trace element signature. Applied Geochemistry, 2012, 27, pp.715-728. 10.1016/j.apgeochem.2011.12.001 . insu-00656034

\section{HAL Id: insu-00656034 https://hal-insu.archives-ouvertes.fr/insu-00656034}

Submitted on 17 Jan 2012

HAL is a multi-disciplinary open access archive for the deposit and dissemination of scientific research documents, whether they are published or not. The documents may come from teaching and research institutions in France or abroad, or from public or private research centers.
L'archive ouverte pluridisciplinaire HAL, est destinée au dépôt et à la diffusion de documents scientifiques de niveau recherche, publiés ou non, émanant des établissements d'enseignement et de recherche français ou étrangers, des laboratoires publics ou privés. 


\title{
Discrimination between different water bodies from a multilayered aquifer (Kaluvelly watershed, India): Trace element signature
}

\author{
Nathalie Gassama ${ }^{\mathrm{a}}$, Haino Uwe Kaspe ${ }^{\mathrm{b}}$, Aline Dia ${ }^{\mathrm{c}}$, Constantin Cocirt ${ }^{\mathrm{a}}$, Martine \\ Bouhnik-LeCo ${ }^{\mathrm{c}}$ \\ ${ }^{a}$ Université François Rabelais - Tours, CNRS/INSU, Université d'Orléans, UMR 6113 \\ ISTO, Parc de Grandmont, 37200 Tours, France \\ ${ }^{\mathrm{b}}$ Institut für Geologie und Mineralogie, Universität zu Köln, Germany \\ ${ }^{\mathrm{c}}$ UMR 6118-Géosciences Rennes, Université de Rennes, Campus Beaulieu, av. du \\ Général Leclerc, 35042 Rennes cedex, France
}

\begin{abstract}
In the multilayered aquifer of Kaluvelly (India), comprising various sedimentary layers overlying a charnockitic basement, concentrations of trace elements were measured in aquifer formations and in groundwaters to identify geochemical tracers for water bodies. The two main sandstones (Cuddalore and Vanur) originate from the charnockites and the Cuddalore sandstone has experienced lateritization. In the studied area, two charnockite end-members were identified: a dioritic and a granitic one. Mineralogical composition and whole-rock Ti concentrations confirmed the charnockite which displayed the granitic composition as the parent rock of the two sandstones. Titanium distribution indicates that the Cuddalore sandstone originates from a more intense weathering of the parent material than the Vanur sandstone. Despite extensive differences in trace element contents recorded in aquifer formations, only a few trace elements were suitable to distinguish the water bodies. Among soluble elements, Li (in the Vanur aquifer) and $\mathrm{Ba}$ (in the charnockite and carbonaceous aquifers) can be used as tracers. As the input of these elements in solution is mainly regulated by the available stock, for a given mineralogical origin there is a direct link between the aquifer formation composition and water signature. With the exception of As, concentrations of redox-sensitive elements were not preserved during pumping because of oxidation, preventing their use as tracers. Low-mobility elements such as $\mathrm{La}, \mathrm{Ce}, \mathrm{Th}, \mathrm{Zr}, \mathrm{Nb}$, Hf, or Ta were too insoluble to be detected in waters and/or to record the aquifer formation signature. Their input in solution was not regulated by the available stock but by the dissolution rate of rock-forming minerals. Only Ti can be used to distinguish between two out of the three aquifers (charnockite and Vanur). The specific behavior of Ti recorded in these waters may be linked to rutile inclusions within plagioclases and to the influence of climate on Ti solubility.
\end{abstract}




\section{Highlights}

Trace elements were measured in aquifer formations and related groundwaters.

Redox-sensitive elements cannot be used as tracers because of pumping.

Soluble elements can be tracers if they occur in little type of minerals.

$\mathrm{Na}$ versus $\mathrm{Ti}$ and $\mathrm{Ca}$ versus $\mathrm{Ti}$ allow differentiating between water sources.

\section{Introduction}

The geochemical signature of a water body is linked to (i) the mineralogical and chemical composition of the aquifer formation, (ii) the chemical characteristics of infiltration waters ( $\mathrm{pH}, \mathrm{Eh}, \mathrm{pCO}_{2}$, etc.), (iii) the surface exchange, (iv) the physical and biogeochemical conditions prevailing in the aquifer, and (v) the interaction time between water and rock. In addition, the management of groundwater resource requires the understanding of water source and hydraulic connections and mixing throughout the aquifer to prevent quality and quantity deterioration.

The Kaluvelly watershed in Tamil Nadu, India, comprises a crystalline bedrock (charnockites) overlain near the coast by sedimentary layers which constitute a multilayered aquifer (Fig. 1). The Kaluvelly swamp, replenished with brackish waters, represents the termination of the surface drainage area, in the north of the catchment. The two main sedimentary layers, the Vanur and the Cuddalore sandstones, result from the weathering of charnockites (granulites). A scientific study monitored these aquifers to assess water quality and water circulation and mixing ( [D'Ozouville et al., 2006] and [Gassama et al., 2011]). Due to the similar composition of the main aquifer formations (charnockites, and the Vanur and Cuddalore sandstones), the difference between the major element signatures recorded in the aquifers was too small to enable the water bodies to be markedly differentiated (Gassama et al., 2011). In addition, hydraulic connections, both natural and those induced through non-cased boreholes, reduced any small differences in chemical signature. The strong variability of ${ }^{87} \mathrm{Sr} /{ }^{86} \mathrm{Sr}$ ratios recorded in charnockites, together with the ${ }^{87} \mathrm{Sr} /{ }^{86} \mathrm{Sr}$ signature of fertilizers (the Vanur recharge), complicated the use of such tracers. 

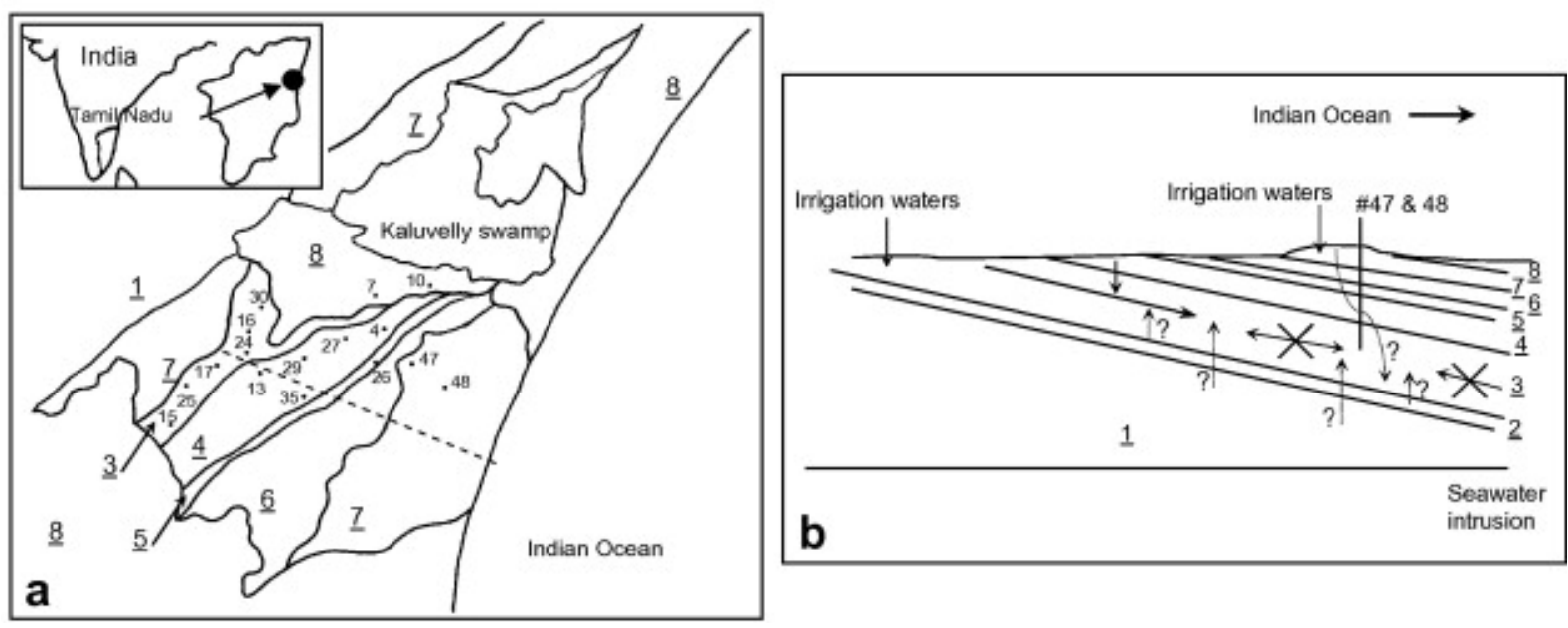

Fig. 1. (a) Simplified geological map and location of Vanur wells. (1) charnockite, (2) Ramanathapuram sandstone, (3) Vanur sandstone, (4) Ottai clay with limestone lenses, (5) Kadaperikuppam limestone, (6) Manaveli clay + Turuvai limestone, (7) Cuddalore sandstone, (8) alluvium. (b) General water flow in the Vanur aquifer: identified (full arrow) and potential (dashed arrow) contributions. No seawater was evidenced and deepest boreholes from the western area seemed to be disconnected from those (\#47 and 48) from the eastern area (crossed arrow).

To complement major elements, isotopic data on elements such as $\mathrm{O}, \mathrm{H}, \mathrm{Sr}$, and sometimes $\mathrm{S}$, are widely used to identify end-members involved in the groundwater signature (e.g. [Armstrong et al., 1998], [Gosselin et al., 2004], [Brenot et al., 2008] and [Raiber et al., 2009]). In order to identify the origin of salinity, the use of elemental and isotopic compositions of B (e.g. [Vengosh et al., 1999] and [Sánchez-Martos et al., 2002]) and Cl (e.g. [Kaufmann et al., 1993] and [Lavastre et al., 2005]) have been developed. Data on trace elements are scarcely used to identify aquifer end-members or to describe groundwater flow. The potential use of elements such as Re, Mo, U (Hodge et al., 1996) or As and other oxyanion-forming trace elements (Vinson et al., 2011) is limited to oxic waters because of their solubility. Lanthanide elements can be used as tracers (Stetzenbach et al., 2001) but only rarely have both water and aquifer formations been analyzed (Banks et al., 1999).

Here, a complementary study, dedicated to trace element fingerprinting and focused on the three main aquifers, was undertaken. Both aquifer formations and waters were investigated in order to distinguish the different water body signatures. The aim was to determine whether trace elements can be used as specific tracers of the end-members involved (Cuddalore and Vanur sandstones, charnockites). To assess the specificity of potential tracers, samples recovered from three secondary aquifers, which are components of the multilayered aquifer, were also studied. The interest in the Kaluvelly case is that the parent material of the two sandstones are the charnockites, providing, for a given trace element, a common mineralogical origin. Thus, for a given trace element, the dissolution rate of the minerals involved should be the same for all three aquifers for given physico-chemical conditions. Although the main hydraulic connections have previously been established, data on trace elements could also improve the description of mixing between water bodies. Knowledge of hydraulic connections throughout the aquifer is essential for better management of this resource, and this work could provide key information for aquifer management in such an area. The impact of fertilizers was also assessed. 


\section{Study area}

Data on climate, hydrology, hydrogeology and a piezometric map for June 2000 are presented in D'Ozouville et al. (2006). Complementary data on geology, location and description of wells, historical piezometric data and a piezometric map for June 2001 are presented in Gassama et al. (2011).

The over-exploitation of aquifers has resulted in a piezometric depression in the Vanur sandstone aquifer, which has modified the natural groundwater flow and which will potentially lead to a degradation of water quality (D'Ozouville et al., 2006). Several possible causes of salinization have been identified: (i) saline intrusion, (ii) infiltration of brackish waters from the Kaluvelly swamp, (iii) input linked to agricultural practices, and (iv) upward migration of older more saline groundwaters in response to the hydraulic gradient.

A simplified cross section of the sedimentary part is presented in Fig. 1b. Results for major elements and isotope ratios $\left({ }^{18} \mathrm{O} /{ }^{16} \mathrm{O},{ }^{2} \mathrm{H} /{ }^{1} \mathrm{H},{ }^{87} \mathrm{Sr} /{ }^{86} \mathrm{Sr}\right)$ revealed the recharge of the Vanur aquifer and slight mixing between aquifers varying according to monsoon input (Gassama et al., 2011). No seawater intrusion could be identified. The recorded salinity originated mainly from water-rock interaction. Hydraulic disconnection of some of the deepest parts of the Vanur aquifer occurred which can be linked to the balance between abstraction and recharge or to lithologic heterogeneities. The underlying charnockite aquifer which could potentially contain saline water was suspected to contribute to the deeper parts of Vanur. Infiltration of waters from the Kaluvelly swamp was suspected in the northern part of the aquifer (wells \#7 and 10). In addition, a contribution from the Cuddalore aquifer was suspected through wells \#47 and \#48.

\section{Sampling and analytical procedure}

\subsection{Sampling}

The wells sampled were located in one of the three main aquifers, the Vanur and Cuddalore sandstones and the charnockite aquifers, and of some intermediate ones (the Ottai clay, the Turuvai and Kadaperikuppam limestone aquifers) (Fig. 1). Priority was given to cased boreholes. Waters were collected during five monitoring surveys spread from January 1999 to October 2001. Waters sampled in January 2001 (after the winter monsoon, HC survey) and in October 2001 (before the next winter monsoon, HE survey) were used to study trace elements. Based on results for major elements, the seasonal variation was assumed to be negligible for the Vanur and the charnockite aquifers and mainly recorded in the Cuddalore aquifer (Gassama et al., 2011).

Aquifer formations were sampled at the outcrop, inside the formation. One sample was selected for sandstone. As charnockites are known to be heterogeneous, two samples (\#1 and \#2) were collected. Several thin sections of each sample have been prepared. Samples were assumed to have not been modified by weathering processes according to the surface aspect together with the thin section study.

Analyses of major elements in aquifer formations were performed using X-ray fluorescence with a Philips PW2400 spectrometer using the "oxiquant" analytical procedure. Seventy-two natural rocks and clays were used as certified reference materials (CRMs) for calibration. The CIPW norm was used to calculate the mineralogical composition from the chemical one. 
Sampling and analytical procedures, and results of analyses of the major elements in waters from the January and October 2001 surveys can be found in Gassama et al. (2011).

Ion charges have been omitted, in all the text, for simplicity.

\subsection{Rock digestion}

Rock samples were crushed in an agate mortar and then dried at $105^{\circ} \mathrm{C}$ overnight (dry basis) prior to analysis. Digestion of samples $(100 \mathrm{mg})$ was carried out using a microwave digestion system (Multiwave Sample Preparation System, Perkin Elmer/Paar Physica) with HF and $\mathrm{HClO}_{4}$ at high pressure $\left(50-60\right.$ bar) and temperature $\left(210{ }^{\circ} \mathrm{C}\right)$. After evaporation of $\mathrm{HClO}_{4}$ and two consecutive evaporation steps with $\mathrm{HCl}$, the residues were dissolved in $\mathrm{HNO}_{3}$ and made up to $50 \mathrm{~mL}$ in volumetric flasks (final solution $2 \% \mathrm{HNO}_{3}$ ) and stored in polyethylene bottles. The efficiency of digestion was checked and confirmed using a high pressure digestion system (PDS, Pressure Digestion System, Loftfields Analytical Solutions) following the same steps as described above. All reagents and water used were of high purity.

\subsection{Trace element analyses}

Concentrations of trace elements in the January 2001 survey waters were determined by inductively coupled plasma mass-spectrometry (ICP-MS, Agilent Technologies HP 4500), using In as an internal standard. The international geostandard SLRS-4 was used to check the accuracy and reproducibility of the results. Typical uncertainties, including all error sources, were below $\pm 5 \%$ for all the trace elements ( [Yeghicheyan et al., 2001] and [Pédrot et al., 2010]).

October 2001 survey water and rock analyses were performed using inductively coupled plasma quadrupole mass-spectrometry (ICP-MS, Perkin Elmer/Sciex Elan 6000). The sample dilution factor ranged from 2-100 (water) and from 500-5000 (digestions) depending on the concentration of elements. Measurements of element concentrations were performed using $\mathrm{Ru}-\mathrm{Re}(10 \mathrm{ng} / \mathrm{mL})$ as internal standards and two calibration solutions (high purity chemical reagents). Calibration solutions were prepared from mono-elemental ICP-MS standard solutions and high purity chemical reagents (Merck). A batch of 5-7 samples was bracketed through two calibration procedures. Accuracy and precision of determinations were checked at regular intervals with certified reference materials (rocks: CRM; waters: NIST 1643d, NIST 1640, NRCC SLRS-4) with compositions similar to the analyzed samples ( [Govindaraju, 1994] and [Dulski, 2001]).

The following trace elements were measured in the rocks: $\mathrm{Li}, \mathrm{Be}, \mathrm{V}, \mathrm{Cr}, \mathrm{Co}, \mathrm{Ni}, \mathrm{Cu}, \mathrm{Zn}, \mathrm{Ga}$, Ge, As, Se, Rb, Sr, Y, Zr, Nb, Cs, Ba, La, Ce, Pr, Nd, Sm, Eu, Gd, Tb, Dy, Ho, Er, Tm, Yb, $\mathrm{Lu}, \mathrm{Hf}, \mathrm{Ta}, \mathrm{Pb}$, Th and $\mathrm{U}$. In waters, the following elements were measured: $\mathrm{Fe}, \mathrm{Mn}, \mathrm{Li}, \mathrm{Rb}$, $\mathrm{Sr}, \mathrm{Ba}, \mathrm{Al}, \mathrm{Cr}, \mathrm{Cu}, \mathrm{Zn}, \mathrm{Cd}, \mathrm{Pb}, \mathrm{Th}, \mathrm{U}, \mathrm{La}$, and Ce in the January 2001 series; Fe, Mn, Li, Be, $\mathrm{B}, \mathrm{Rb}, \mathrm{Sr}, \mathrm{Ba}, \mathrm{Al}, \mathrm{Ge}, \mathrm{As}, \mathrm{Se}, \mathrm{Sc}, \mathrm{Ti}, \mathrm{V}, \mathrm{Cr}, \mathrm{Co}, \mathrm{Ni}, \mathrm{Cu}, \mathrm{Zn}, \mathrm{Mo}, \mathrm{Cd}, \mathrm{Pb}$, Th and $\mathrm{U}$ in the October 2001 series.

\section{Aquifer formation - Lithologic characteristics}

The geological basement mostly consists of charnockites (Madras Granulite Block) which outcrop on the west and are overlain by sedimentary layers close to the coast. This sedimentary cover consists of alternating layers of sandstones, claystones and limestones. 
This cover and the charnockites constitute a multilayered aquifer. The layers dip and thicken toward the sea (eastward) to a depth of up to $500 \mathrm{~m}$ (Jaya Kumar et al., 1984). Several aquifer formations have been recorded from the bottom to the top of the stratigraphic sequence (Fig. 1): the charnockites, Ramanathapuram sandstone, Vanur sandstone, Ottai clay (containing limestone lenses), Turuvai limestone, Kadaperikuppam limestone, Manaveli clay and Cuddalore sandstone. Three main aquifers are used for water supply (mainly for irrigation but also for domestic purposes): (i) the charnockite, (ii) the Vanur sandstone, (iii) and the Cuddalore sandstone aquifers.

Charnockites of the Indian peninsula originate from different geological events ( [Bhattacharya, 1996], [Mezger and Cosca, 1999] and [Rickers et al., 2001]). The Madras Granulite Block, sometimes referred to as the Eastern Ghats coastal belt, exhibits variable composition from acidic to basic granulites (Weaver et al., 1978). This group has a complex differentiation signature (Sen, 1974) consisting of protoliths originating from different magmas (Weaver et al., 1978). In addition, some studies have revealed that metasomatic processes have affected alkali elements and REE distribution; thus only a few rocks may have preserved their primary signatures (Bernard-Griffiths et al., 1987). Consequently, the studied charnockite aquifer may exhibit a broad range of chemical and mineralogical compositions and thus isotopic signatures. Based on field observations, two samples representative of local charnockites were collected. Thin section observation showed a composition of alkali feldspar, quartz, plagioclase, biotite, pyroxene, green hornblende, epidote, rutile, hydrous ferric oxides and apatite. This microscopic study and chemical analyses (Table 1 and Table 2) evidenced that the charnockites sampled exhibited a dioritic (\#1) and a granitic (\#2) composition. Owing to the physical properties of the rock, water circulates in the charnockite aquifer through fissures and in weathered rock pockets. This may lead to heterogeneity in the chemical signature of the water.

Table 1. CIPW normal composition of sampled charnockites expressed as\% weight.

\begin{tabular}{|c|c|c|}
\hline \multicolumn{3}{|c|}{ \% weight Charn1 Char } \\
\hline Quartz & 1.9 & 34.6 \\
\hline Albite & 19.9 & 31.4 \\
\hline Anorthite & 25.3 & 13.3 \\
\hline Orthose & 5.0 & 13.9 \\
\hline Diopside & 17.3 & 0.0 \\
\hline Enstatite & 5.2 & 1.6 \\
\hline Ferrosilite & 21.3 & 2.9 \\
\hline Apatite & 0.3 & 0.0 \\
\hline Ilmenite & 2.4 & 0.2 \\
\hline Pyrolusite & 0.2 & 0.0 \\
\hline Total & 98.8 & 98.0 \\
\hline
\end{tabular}


Table 2. Major element composition of host rocks (charnockite, Vanur and Cuddalore sandstone), and normalized composition to parent rocks.

\begin{tabular}{|c|c|c|c|c|c|c|c|c|}
\hline $\mathrm{mg} / \mathrm{g}$ & charnockite 1 & $\begin{array}{c}\text { charnockite } \\
2 \\
\end{array}$ & $\begin{array}{c}\text { Vanur } \\
\text { sandstone }\end{array}$ & $\begin{array}{l}\text { Cuddalore } \\
\text { sandstone }\end{array}$ & $\begin{array}{l}\text { Vanur/ } \\
\text { charn1 }\end{array}$ & $\begin{array}{l}\text { Vanur/ } \\
\text { charn2 }\end{array}$ & $\begin{array}{l}\text { Cudd/ } \\
\text { charn1 }\end{array}$ & $\begin{array}{l}\text { Cudd/ } \\
\text { charn2 }\end{array}$ \\
\hline $\mathrm{SiO}_{2}$ & 52.13 & 73.19 & 84.2 & 72.66 & 1.62 & 1.15 & 1.39 & 0.99 \\
\hline $\mathbf{A l}_{2} \mathbf{O}_{3}$ & 14.07 & 13.54 & 4.03 & 2.83 & 0.29 & 0.30 & 0.20 & 0.21 \\
\hline $\mathrm{Fe}_{2} \mathrm{O}_{3}$ & 14.17 & 1.99 & 3.09 & 15.33 & 0.22 & 1.55 & 1.08 & 7.70 \\
\hline MgO & 5.29 & 0.64 & 1.06 & 0.1 & 0.20 & 1.66 & 0.02 & 0.16 \\
\hline $\mathrm{CaO}$ & 9.76 & 2.67 & 1.16 & 0.05 & 0.12 & 0.43 & 0.01 & 0.02 \\
\hline $\mathrm{Na}_{2} \mathrm{O}$ & 2.37 & 3.69 & 0.33 & 0.08 & 0.14 & 0.09 & 0.03 & 0.02 \\
\hline $\mathrm{K}_{2} \mathrm{O}$ & 0.81 & 2.39 & 1.72 & 0.03 & 2.12 & 0.72 & 0.04 & 0.01 \\
\hline $\mathrm{TiO}_{2}$ & 1.26 & 0.23 & 0.84 & 3.61 & 0.67 & 3.65 & 2.87 & 15.70 \\
\hline MnO & 0.19 & 0.03 & 0.07 & 0.08 & 0.37 & 2.33 & 0.42 & 2.67 \\
\hline $\mathbf{P}_{2} \mathbf{O}_{5}$ & 0.16 & $<0.03$ & $<0.03$ & 0.07 & & & & \\
\hline LOI & 0.24 & 0.71 & 1.86 & 3.49 & & & & \\
\hline Total & 100.45 & 99.11 & 98.39 & 98.33 & & & & \\
\hline
\end{tabular}

Vanur sandstone outcrops in the west and becomes confined below Ottai clays eastward. The Cuddalore sandstone occurs as small plateaus on the east and west sides of the sedimentary cover. Lateritization processes have affected the exposed surface of the Cuddalore sandstone, which is capped by a ferruginised lag deposit (about $50 \mathrm{~cm}$ thick) (Bourgeon, 1988). Nodules of the lag deposit are coated with a thin film of Fe(III) oxides (goethite, hematite, magnetite) and the matrix between the nodules is rich in Fe(III) and kaolinite (Achyuthan, 1996). The ferricrete cap is thought to have been formed during the Late Tertiary to the Early Pleistocene during the uplift of the charnockite bedrock ( [Bourgeon, 1988] and [Achyuthan, 1996]). This uplift accounts for the scouring of the top formation. The Vanur sandstone mostly consists of rounded silicate grains (quartz, feldspar, muscovite, biotite, zircon, epidote, garnet, kyanite, tourmaline and green hornblende), which were consolidated with carbonate cement. The superficial Cuddalore sandstone comprises rounded, coarse and angular fine grains, mono(mainly metamorphized quartz but also feldspar) or poly-crystalline, either coarse and rounded or fine and angular, coated with Fe(III) oxides. Some rutile, sphene, zircon, pyroxene and kyanite minerals were also observed. The permeability of these sandstones allows the flow of significant quantities of water (Jaya Kumar et al., 1984), the water body of each aquifer can be considered to be relatively homogeneous in contrast to charnockite.

\section{Aquifer formation - Results and discussion}

\subsection{Chemical evolution during weathering}

\subsubsection{Weathering intensity}

The parent material of the Vanur sandstone has experienced one main weathering episode. In the case of the Cuddalore, the lateritization process has modified the chemical and mineralogical distribution resulting from the sandstone formation. The two sandstones are depleted in $\mathrm{Al}, \mathrm{Ca}$ and $\mathrm{Na}$ compared to the charnockites (Table 2), which can be attributed to the weathering of ferromagnesian silicates and plagioclase. Considering the low solubility of 
Al, the high depletion observed suggests a significant loss of matter. Weathering induces a decrease in $\mathrm{K}$, which is a mobile ion occurring in feldspar, and an increase in Ti, a lowmobility ion occurring in poorly soluble phases (e.g. rutile as a primary or secondary mineral). The variation in $\mathrm{K}$ and $\mathrm{Ti}$ concentrations (Table 2) suggests that the parent rocks of the two sandstones may be more closely related to charnockite \#2 than to charnockite \#1. Likewise, the chemical and mineralogical composition of the Vanur sandstone was more closely related than that of the Cuddalore sandstone to the parent rocks. The Cuddalore sandstone recorded a more intense weathering process (Table 2). This was confirmed by thin section microscopic observation (cf. Section 4). Hence, an increasing chemical gradient from charnockite \#2, Vanur to Cuddalore sandstone could be observed.

\subsubsection{Alkali and alkaline earth elements}

Charnockite \#2 contained the highest concentration of Ba (Table 3). The Vanur sandstone was enriched in $\mathrm{Mg}$ (Table 2), $\mathrm{Li}, \mathrm{Rb}$ and $\mathrm{Cs}$ (Table 3) compared to charnockite \#2. This could be explained by clay entrapment (Nesbitt et al., 1980) because the concentration of these mobile elements decreases during weathering (of feldspars and micas). A similar pattern was not observed for the Cuddalore sandstone. This result is in accordance with a more intense weathering process of the Cuddalore formation in the post consolidation period. With regard to charnockite \#2, the Vanur was depleted in $\mathrm{Be}, \mathrm{Sr}$ and $\mathrm{Ba}$, and the Cuddalore sandstone was depleted in all the elements of this group.

Table 3. Trace element composition of host rocks (charnockite, Vanur and Cuddalore sandstone), and normalized composition to parent rocks. Elements are classified according to chemical properties and atomic numbers. 


\begin{tabular}{|c|c|c|c|c|c|c|c|c|}
\hline$\mu \mathrm{g} / \mathrm{g}$ & charnockite 1 & charnockite 2 & $\begin{array}{c}\text { Vanur } \\
\text { sandstone }\end{array}$ & $\begin{array}{l}\text { Cuddalore } \\
\text { sandstone }\end{array}$ & $\begin{array}{l}\text { Vanur/ } \\
\text { charn1 }\end{array}$ & $\begin{array}{l}\text { Vanur/ } \\
\text { charn2 }\end{array}$ & $\begin{array}{l}\text { Cudd/ } \\
\text { charn1 }\end{array}$ & $\begin{array}{l}\text { Cudd/ } \\
\text { charn2 }\end{array}$ \\
\hline $\mathbf{L i}$ & 11.5 & 10.2 & 14.3 & 1.8 & 1.2 & 1.4 & 0.2 & 0.2 \\
\hline $\mathrm{Be}$ & 0.5 & 0.8 & 0.0 & 0.4 & 0.0 & 0.0 & 0.8 & 0.5 \\
\hline $\mathbf{R b}$ & 27.5 & 28.9 & 42.6 & 0.7 & 1.5 & 1.5 & 0.0 & 0.0 \\
\hline Sr & 132.7 & 419.0 & 85.5 & 4.0 & 0.6 & 0.2 & 0.0 & 0.0 \\
\hline Cs & 1.0 & 0.1 & 0.2 & 0.1 & 0.2 & 2.0 & 0.1 & 1.0 \\
\hline $\mathrm{Ba}$ & 242.7 & 1066.3 & 549.2 & 116.3 & 2.3 & 0.5 & 0.5 & 0.1 \\
\hline V & 351.3 & 26.9 & 41.2 & 170.7 & 0.1 & 1.5 & 0.5 & 6.3 \\
\hline $\mathrm{Cr}$ & 112.9 & 8.3 & 34.5 & 439.5 & 0.3 & 4.2 & 3.9 & 53.0 \\
\hline Co & 47.9 & 5.7 & 4.9 & 19.1 & 0.1 & 0.9 & 0.4 & 3.4 \\
\hline $\mathrm{Ni}$ & 77.1 & 8.6 & 3.2 & 51.0 & 0.0 & 0.4 & 0.7 & 6.0 \\
\hline $\mathrm{Cu}$ & 180.1 & 57.0 & 6.4 & 50.7 & 0.0 & 0.1 & 0.3 & 0.9 \\
\hline $\mathbf{Z n}$ & 133.4 & 48.3 & 41.5 & 96.4 & 0.3 & 0.9 & 0.7 & 2.0 \\
\hline $\mathbf{P b}$ & 3.72 & 10.51 & 10.13 & 92.77 & 2.7 & 1.0 & 24.9 & 8.8 \\
\hline $\mathbf{G a}$ & 19.0 & 16.9 & 4.2 & 10.8 & 0.2 & 0.2 & 0.6 & 0.6 \\
\hline Ge & 0.1 & 0.1 & 0.0 & 0.5 & 0.0 & 0.0 & 5.0 & 5.0 \\
\hline As & 1.4 & 2.0 & 1.8 & 6.2 & 1.3 & 0.9 & 4.5 & 3.1 \\
\hline Se & 3.3 & 0.3 & 0.6 & 6.4 & 0.2 & 1.8 & 2.0 & 19.7 \\
\hline $\mathbf{Y}$ & 25.1 & 1.1 & 13.9 & 23.9 & 0.6 & 12.6 & 1.0 & 21.7 \\
\hline La & 10.0 & 16.0 & 15.2 & 183.3 & 1.5 & 1.0 & 18.3 & 11.5 \\
\hline $\mathrm{Ce}$ & 22.7 & 22.9 & 36.0 & 974.7 & 1.6 & 1.6 & 42.9 & 42.6 \\
\hline Pr & 2.8 & 1.8 & 3.0 & 42.7 & 1.1 & 1.7 & 15.0 & 23.2 \\
\hline Nd & 12.5 & 5.6 & 10.8 & 153.1 & 0.9 & 1.9 & 12.2 & 27.3 \\
\hline Sm & 3.16 & 0.55 & 1.93 & 22.84 & 0.6 & 3.5 & 7.2 & 41.3 \\
\hline $\mathbf{E u}$ & 1.03 & 0.79 & 0.34 & 1.54 & 0.3 & 0.4 & 1.5 & 1.9 \\
\hline Gd & 4.03 & 0.31 & 2.13 & 14.84 & 0.5 & 6.9 & 3.7 & 48.0 \\
\hline $\mathbf{T b}$ & 0.69 & 0.05 & 0.38 & 1.78 & 0.6 & 7.6 & 2.6 & 35.6 \\
\hline Dy & 4.63 & 0.19 & 2.45 & 7.31 & 0.5 & 12.9 & 1.6 & 38.5 \\
\hline Но & 1.04 & 0.05 & 0.53 & 1.15 & 0.5 & 10.6 & 1.1 & 23.0 \\
\hline Er & 3.01 & 0.12 & 1.58 & 2.55 & 0.5 & 13.2 & 0.8 & 21.3 \\
\hline $\mathrm{Tm}$ & 0.46 & 0.03 & 0.24 & 0.33 & 0.5 & 8.0 & 0.7 & 11.0 \\
\hline $\mathbf{Y b}$ & 2.96 & 0.15 & 1.60 & 2.20 & 0.5 & 10.7 & 0.7 & 14.7 \\
\hline Lu & 0.45 & 0.03 & 0.24 & 0.31 & 0.5 & 8.0 & 0.7 & 10.3 \\
\hline Th & 1.97 & 0.38 & 7.21 & 103.10 & 3.7 & 18.8 & 52.3 & 268.8 \\
\hline $\mathbf{U}$ & 0.51 & 0.17 & 0.51 & 3.23 & 1.0 & 2.9 & 6.3 & 18.6 \\
\hline $\mathbf{Z r}$ & 84.3 & 61.9 & 79.2 & 303.9 & 0.9 & 1.3 & 3.6 & 4.9 \\
\hline $\mathbf{N b}$ & 3.9 & 2.4 & 11.4 & 55.4 & 2.9 & 4.8 & 14.2 & 23.3 \\
\hline Hf & 2.45 & 1.87 & 2.12 & 7.96 & 0.9 & 1.1 & 3.2 & 4.3 \\
\hline Ta & 0.36 & 0.34 & 0.37 & 2.24 & 1.0 & 1.1 & 6.2 & 6.6 \\
\hline
\end{tabular}

enriched wirh reference to charnockites

depleted with reference to charnockites

\subsubsection{Transition elements, $\mathrm{Ga}, \mathrm{Ge}, \mathrm{As}$, Se}

The two sandstones were depleted in $\mathrm{Cu}$ and $\mathrm{Ga}$, and enriched in $\mathrm{Fe}, \mathrm{Mn}$ (Table 2), $\mathrm{V}, \mathrm{Cr}, \mathrm{Pb}$, $\mathrm{Ge}, \mathrm{As}$ and Se (Table 3) compared to charnockite \#2. This enrichment was greater for the Cuddalore sandstone, which was also enriched in $\mathrm{Co}, \mathrm{Ni}$ and $\mathrm{Zn}$. The elements of this group are of low mobility under oxidizing conditions, except $\mathrm{V}, \mathrm{Cr}$ and $\mathrm{As}$, and all have high affinities for Fe and/or Mn oxyhydroxides (Buffle and De Vitre, 1994). Differences between the two sandstones may be linked to the lateritization process. 


\subsubsection{Lanthanides, Y, Th, U, High Field Strength Elements (HFSE)}

As lanthanides are low-mobility elements, their concentrations increase in the solid fraction of the residual material when weathering increases. Concentrations of $Y$, lanthanides, Th, $U$ and HFSE (senso stricto: $\mathrm{Zr}, \mathrm{Nb}, \mathrm{Hf}$, Ta) were greater in the two sandstones than in charnockite \#2 (Table 3). The Cuddalore sandstone enrichment was up to 20 times higher. Considering the low $\mathrm{P}_{2} \mathrm{O}_{5}$ content of these rocks, lanthanide and $\mathrm{Y}$ enrichment cannot be attributed to the accumulation of phosphate minerals ( [Banfield and Eggleton, 1989] and [Aubert et al., 2001]). Lanthanide, Y, Th, U and HFSE enrichment could instead be linked to the stability of typical bearing minerals such as zircon or rutile. Carbonate and Fe oxyhydroxide precipitation may also be involved in the accumulation of lanthanides ( [Brookins, 1989], [Sholkovitz et al., 1992] and [de Carlo et al., 1997]), Y, Th, and U in the sandstone of Vanur (carbonate) and Cuddalore (Fe oxyhydroxide), respectively. Europium is divalent and can substitute for $\mathrm{Ca}$ in minerals during rock genesis. As low plagioclase content was observed in the two sandstones, the Eu depletion recorded here may be linked to the weathering of parent-rock plagioclase which is usually enriched in Eu. A high Ce enrichment in sandstones related to the charnockite was also recorded. This positive anomaly is the result of the oxidation of Ce(III) to the immobile form Ce(IV) (Brookins, 1989). This has been observed in several laterite profiles developed on igneous rocks, where Ce was oxidized to cerianite $\left(\mathrm{CeO}_{2}\right)$ in the ferruginous unit and accumulated in higher concentrations than other REE ( [Braun et al., 1990], [Valeton et al., 1997], [Dequincey et al., 2002] and [Ndjigui et al., 2008]).

\subsubsection{General pattern}

Few binary correlations were observed between chemical elements. This may imply that most of the elements were involved in several mechanisms. Potassium and Sr (Fig. 2a and b) exhibited a negative correlation with $\mathrm{Ti}$, whereas $\mathrm{Cr}$ and $\mathrm{Se}$ (Fig. 2c and d) exhibited a positive correlation. These relationships suggest that chemical processes were the main factors governing loss of these elements and that they were involved in the same kinds of chemical reactions. Data distribution (Fig. 2) confirms that charnockite \#2 represents the parent rocks of the sandstones, and the increasing chemical gradient from charnockite \#2, Vanur to Cuddalore sandstone. 

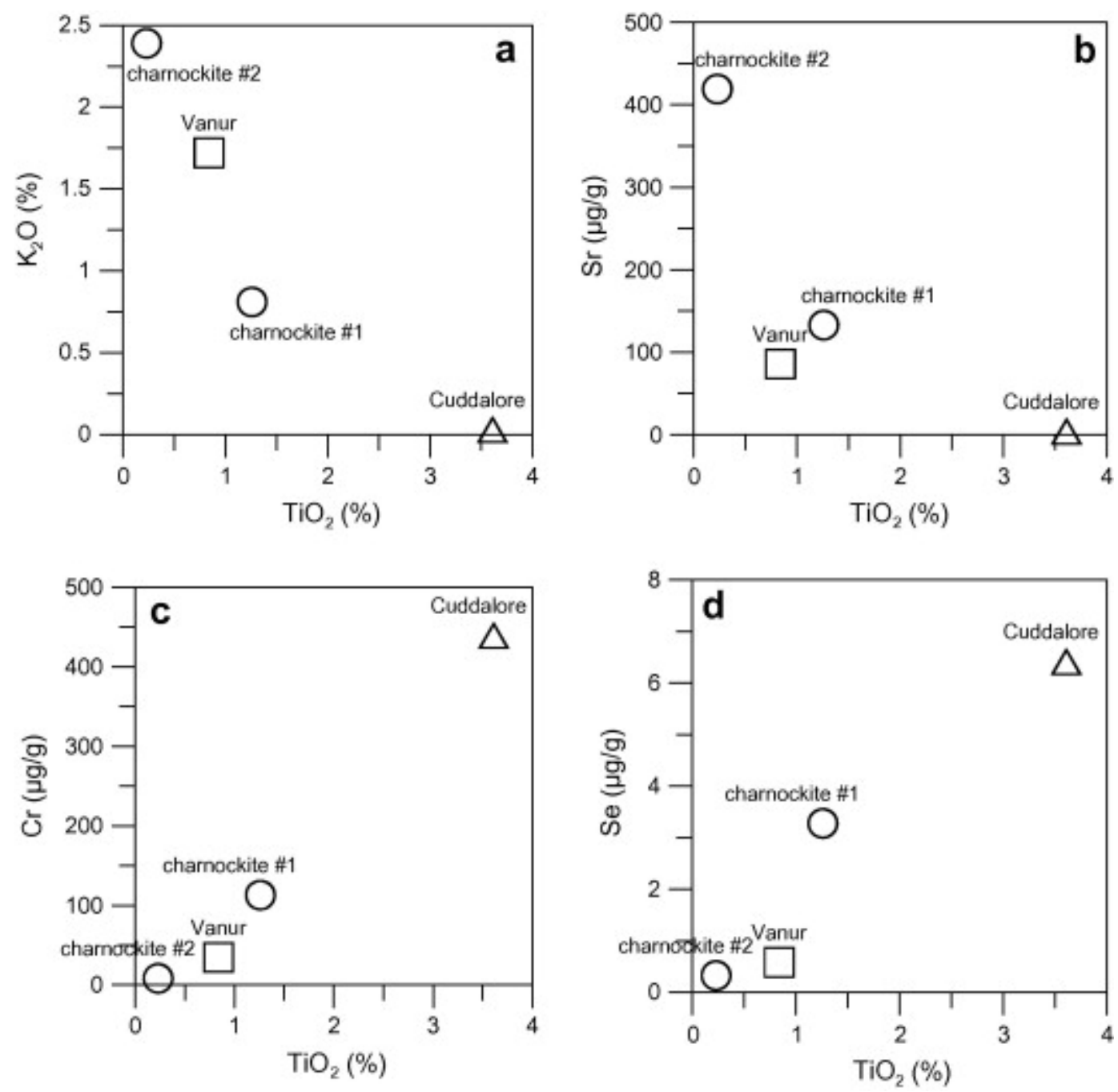

Fig. 2. Distribution of: (a) $\mathrm{K}_{2} \mathrm{O}\left(10^{-2} \mathrm{~g} / \mathrm{g}\right)$, (b) $\mathrm{Sr}(\mu \mathrm{g} / \mathrm{g})$, (c) $\mathrm{Cr}(\mu \mathrm{g} / \mathrm{g})$, and (d) $\mathrm{Se}(\mu \mathrm{g} / \mathrm{g})$ concentration in the aquifer formations as a function of $\mathrm{TiO}_{2}\left(10^{-2} \mathrm{~g} / \mathrm{g}\right)$ concentration.

\subsection{Elementary signature of reservoirs}

Results evidence that the two sandstones resulted from the weathering of charnockite and that charnockite \#2 is the parent rocks. Therefore, charnockite \#2 is likely representative of local charnockite. The Cuddalore sandstone originated from a more intense weathering process than the Vanur sandstone. In addition, elements with high affinities for Fe and/or Mn oxyhydroxydes have accumulated in the Cuddalore formation during lateritization. According to the data specific tracers for the charnockite reservoir are potentially $\mathrm{Be}, \mathrm{Sr}, \mathrm{Ba}, \mathrm{Cu}$ and $\mathrm{Ga}$. Whereas, Fe, Mn, Ti, V, Cr, Pb, Se, Y, lanthanides, Th, U and HFSE could be considered as specific tracers for the two sandstones. To distinguish the two sandstones, Vanur was enriched in $\mathrm{Li}, \mathrm{Rb}$ and $\mathrm{Cs}$, but depleted in $\mathrm{Co}, \mathrm{Ni}, \mathrm{Cu}, \mathrm{Zn}, \mathrm{Ge}, \mathrm{As}$ and $\mathrm{Eu}$.

\section{Trace elements in groundwater - Results and discussion}

While the Cuddalore aquifer is unconfined (\#19, 38, 39, 40, 42, 43, 44, 45, 46, 53), samples from the Vanur aquifer were taken from both the confined (\#4, 7, 10, 13, 26, 27, 29, 35, 47, 
48) and unconfined (\#15, 16, 17, 24, 25, 30) areas. The deepest boreholes are \#4, 7, 13, 29, 35, 47 and 48. Fertilizer contamination was identified in borehole \#16 through Cl contents ( $\mathrm{KCl}$ input; Gassama et al., 2011). Because little information was available on borehole casing, samples from the charnockite aquifer $(\# 2,23,31,32,33,34,49,50,52)$ were collected in the unconfined area to prevent the risk of sampling waters mixed within the borehole.

In all the water samples analyzed, the Na concentration increased steadily in line with the advancement of water-rock interaction (Fig. 3a). By comparing the concentrations of selected elements with that of $\mathrm{Na}$ it was possible to classify boreholes: the lowest end-member comprised the Cuddalore samples, followed by the Vanur recharge waters, whereas the highest end-member comprised the deepest boreholes of the Vanur aquifer and the more mineralized waters of the charnockite aquifer.
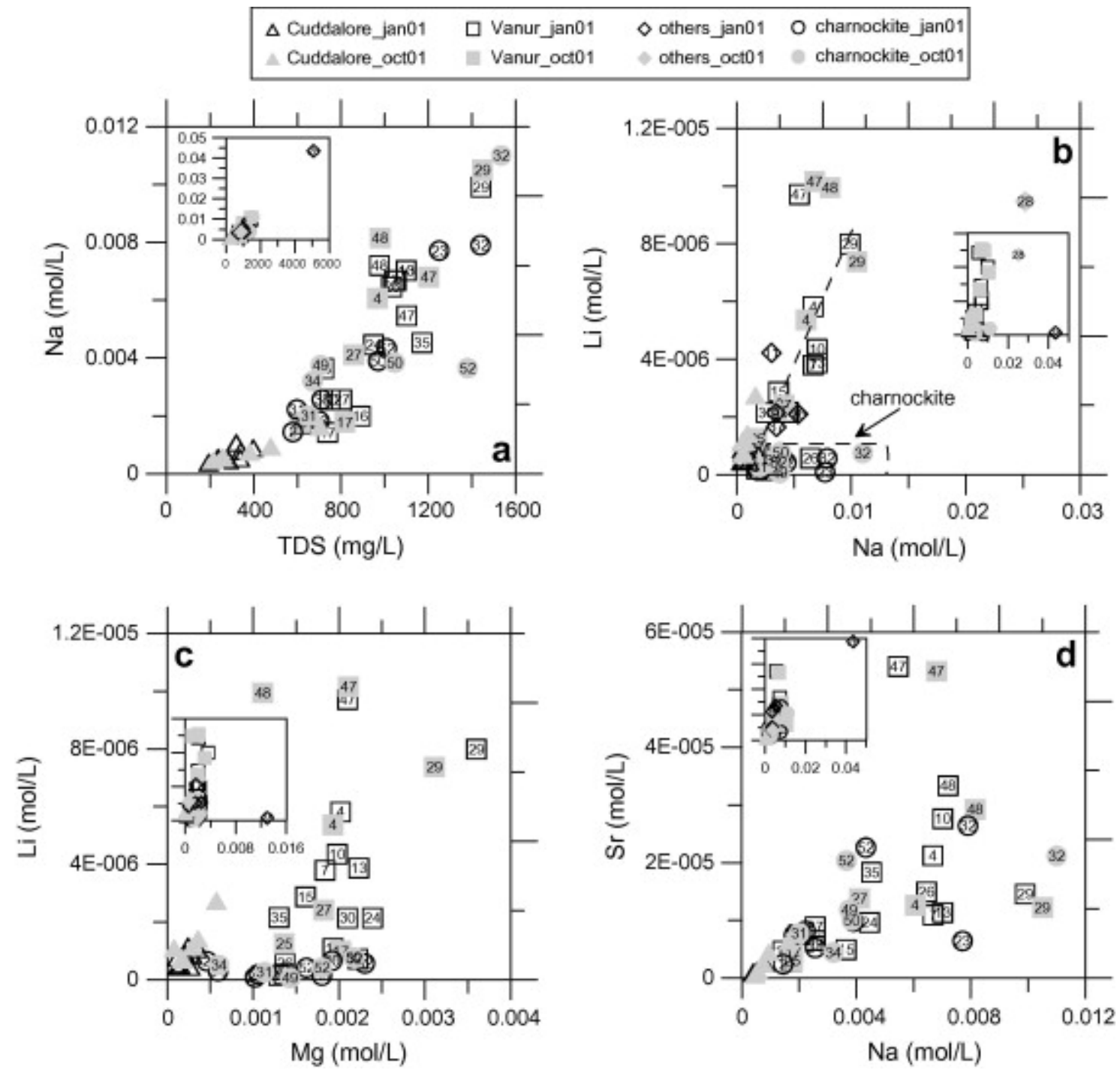

Fig. 3. Distribution of: (a) Na versus TDS, (b) Li versus Na, (c) Li versus $\mathrm{Mg}$, and (d) $\mathrm{Sr}$ versus $\mathrm{Na}$ in water samples (molar concentrations). 


\subsection{Alkali and alkaline earth elements $(\mathrm{Li}, \mathrm{Sr}, \mathrm{Rb}, \mathrm{Ba}, \mathrm{Be})$}

In the charnockite aquifer, waters were Li-depleted (Table $4 \mathrm{a}$ and Table 4b, Fig. 3b) compared to those from Vanur for similar Na concentrations. The range for Cuddalore waters were as for the samples from the Vanur recharge area, from 0.4 to $2.9 \times 10^{-6} \mathrm{~mol} / \mathrm{L}$. In the Vanur aquifer, the correlation (for January and October 2001 series; molar expression) can be calculated as follows:

$[\mathrm{Li}]=9.18 \times 10^{-4}[\mathrm{Na}]-7.80 \times 10^{-7} \quad n=22 \quad R^{2}=0.562$

The weak correlation coefficient was due to \#47 and 48, which were Li-enriched compared to Vanur waters from the other boreholes. In the Vanur, the Li distribution followed the waterrock interaction pattern, and its waters were richer in Li than those from charnockite, in accordance with rock data. The Li distribution between the Cuddalore and the charnockite waters did not match the rock ratio. It, therefore, seems that the available stock and reaction time are not the only significant parameters controlling Li release in these waters; another probable factor is the nature of the Li-bearing mineral. When Li originates from biotite, $\mathrm{Mg}$ and $\mathrm{Li}$ are correlated (Beaucaire and Michard, 1982) because Li substitutes for Mg in the octahedral site. This relationship was not observed in the charnockite waters (Fig. 3c). Lithium can also originate from other micas and from pyroxene (Teng et al., 2008) where it can substitute for $\mathrm{Mg}$ or for Fe(II). As a result, no link with $\mathrm{Mg}$ was observed. In addition, clays found in the soils and superficial parts of the aquifer may alter the Li distribution (Nesbitt et al., 1980). 
Table 4a. January 2001. Trace element concentrations (mol/L) in waters. TDS as mg/L. n.d.: not detected. sw: swamp; V: Vanur, ch: charnockite, K: Kaddaperikuppam, O: Ottai, T: Turuvai, and Cd: Cuddalore aquifer.

$\begin{array}{llcllllllllllllllll}\text { Label } & \text { p } & \text { TD } & \text { Fe } & \text { Mn } & \text { Li } & \text { Rb } & \text { Sr } & \text { Ba } & \text { Al } & \text { Cr } & \text { Cu } & \text { Zn } & \text { Cd } & \text { Pb } & \text { Th } & \text { U } & \text { La } & \text { Ce }\end{array}$

HC ${ }_{r}^{e}{ }^{6} 6 .{ }_{111} 6.88 \mathrm{E} 2.19 \mathrm{E} \quad 5.9 \mathrm{E}-3.01 \mathrm{E} \quad 8.9 \mathrm{E}-1.87 \mathrm{E} 6.00 \mathrm{E} \quad 8.1 \mathrm{E}-1.04 \mathrm{E} 1.62 \mathrm{E}$ n.d. $\quad 8.98 \mathrm{E} 2.15 \mathrm{E} 5.0 \mathrm{E}-4.03 \mathrm{E} 5.85 \mathrm{E}$

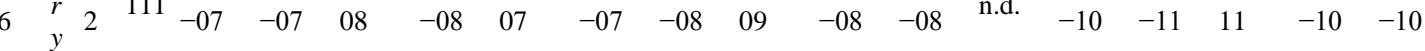

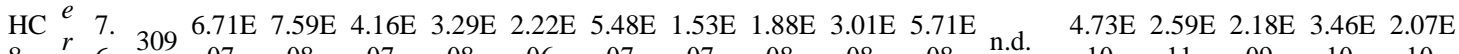

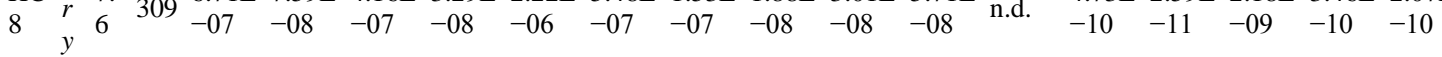

$\mathrm{HC} s \quad 7.9113 .20 \mathrm{E} 1.05 \mathrm{E} \quad 3.87 \mathrm{E}$

$\begin{array}{lllllll}20 & w & 2 & 5 & -08 & -06 & -06\end{array}$

$\mathrm{HC} s$ 7. 102 1.10 $7.6 \mathrm{E}-3.88 \mathrm{E} 1.84 \mathrm{E} \quad 3.68 \mathrm{E} \quad 7.78 \mathrm{E} \quad 1.56 \mathrm{E} \quad 8.66 \mathrm{E} \quad 8.44 \mathrm{E} \quad 7.97 \mathrm{E} \quad 6.9 \mathrm{E}-5.30 \mathrm{E} 5.90 \mathrm{E} 7.15 \mathrm{E} \quad 5.44 \mathrm{E} \quad 1.85 \mathrm{E}$

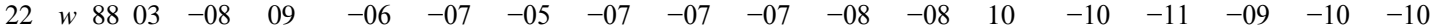

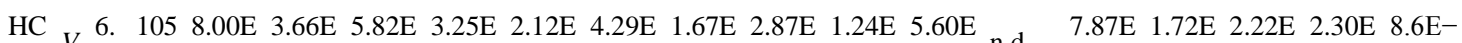
$\begin{array}{lllllllllllllllllll}4 & 69 & 1 & -07 & -08 & -06 & -08 & -05 & -07 & -08 & -08 & -08 & -08 & \text { n.d. } & -10 & -11 & -09 & -10 & 11\end{array}$

$\mathrm{HC}_{V}$ 7. 104 3.47E 6.61E $3.79 \mathrm{E} \quad 6.11 \mathrm{E} \quad 1.10 \mathrm{E}$ 7.13E $5.52 \mathrm{E} \quad 1.81 \mathrm{E} \quad 1.15 \mathrm{E} \quad 2.17 \mathrm{E}$ n.d $2.85 \mathrm{E} \quad 8.6 \mathrm{E}-9.7 \mathrm{E}-1.94 \mathrm{E} \quad 7.9 \mathrm{E}-$

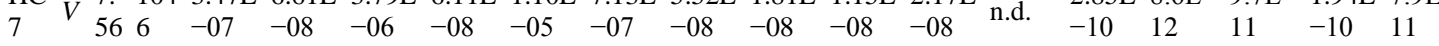

$\mathrm{HC}_{V}$ 6. $1096.50 \mathrm{E} 5.3 \mathrm{E}-4.35 \mathrm{E} 3.49 \mathrm{E} 2.76 \mathrm{E} \quad 1.00 \mathrm{E} \quad 4.63 \mathrm{E} 3.48 \mathrm{E} 1.73 \mathrm{E} \quad 1.39 \mathrm{E}$, $5.26 \mathrm{E} \quad 8.6 \mathrm{E}-8.47 \mathrm{E} \quad 1.37 \mathrm{E} \quad 7.1 \mathrm{E}-$

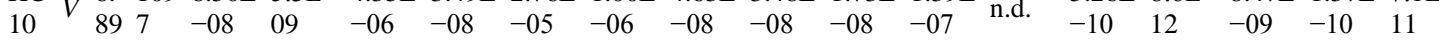
$\mathrm{HC}_{V}$ 7. $1096.16 \mathrm{E} 7.00 \mathrm{E} \quad 3.87 \mathrm{E} 3.03 \mathrm{E} \quad 1.14 \mathrm{E} \quad 9.7 \mathrm{E}-1.49 \mathrm{E} 3.58 \mathrm{E} 1.15 \mathrm{E} \quad 4.22 \mathrm{E}$. 2.41E $6.46 \mathrm{E} 3.48 \mathrm{E} 2.59 \mathrm{E} 2.11 \mathrm{E}$

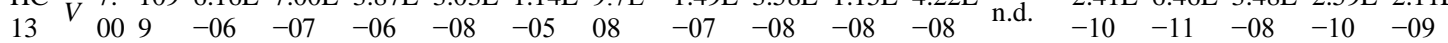
$\mathrm{HC}_{V} 7.7216 .70 \mathrm{E} 2.21 \mathrm{E} 2.87 \mathrm{E} \quad 3.08 \mathrm{E} \quad 4.94 \mathrm{E} \quad 1.14 \mathrm{E} 5.00 \mathrm{E} \quad 9.2 \mathrm{E}-8.7 \mathrm{E}-1.03 \mathrm{E}$. $4.10 \mathrm{E} 1.72 \mathrm{E} 1.30 \mathrm{E} \quad 7.9 \mathrm{E}-2.9 \mathrm{E}-$

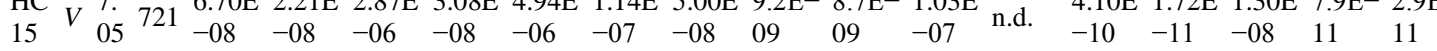
${ }_{16}{ }_{V}{ }_{69}^{6 .} 8896.50 \mathrm{E} \quad 6.8 \mathrm{E}-7.17 \mathrm{E} 2.88 \mathrm{E} 7.51 \mathrm{E} \quad 6.63 \mathrm{E} 2.30 \mathrm{E} \quad 3.44 \mathrm{E} \quad 1.48 \mathrm{E} 2.14 \mathrm{E}$ n.d $5.89 \mathrm{E} \quad 8.6 \mathrm{E}-1.09 \mathrm{E} \quad 6.5 \mathrm{E}-1.4 \mathrm{E}-$

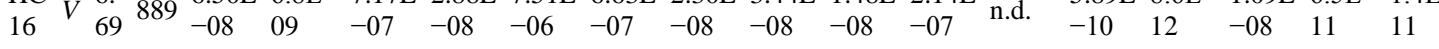

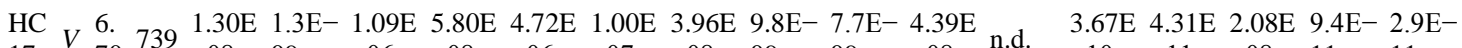

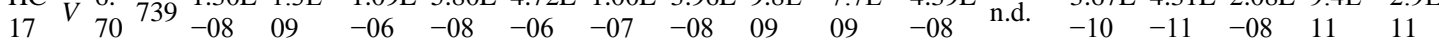
$\mathrm{HC}_{V}{ }^{7 .} 9491.48 \mathrm{E} \quad 1.83 \mathrm{E} \quad 2.14 \mathrm{E} \quad 1.93 \mathrm{E} \quad 9.63 \mathrm{E} \quad 5.2 \mathrm{E}-1.25 \mathrm{E} \quad 3.63 \mathrm{E} \quad 2.33 \mathrm{E} \quad 2.29 \mathrm{E} \quad 8 . \mathrm{E}-1 \quad 3.38 \mathrm{E} \quad 2.59 \mathrm{E} \quad 3.97 \mathrm{E} \quad 1.37 \mathrm{E} \quad 9.3 \mathrm{E}-$

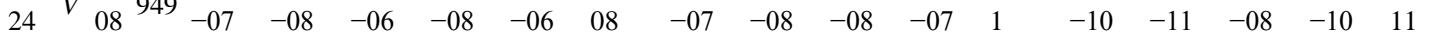

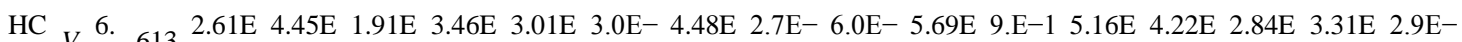

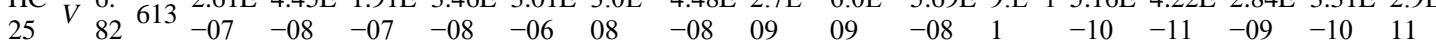
$\mathrm{HC}_{V}$ 6. 103 6.67E $9.51 \mathrm{E} 5.63 \mathrm{E} 1.46 \mathrm{E} \quad 1.50 \mathrm{E} \quad 1.08 \mathrm{E} 2.63 \mathrm{E} 2.73 \mathrm{E} 2.17 \mathrm{E} \quad 3.89 \mathrm{E} 1.0 \mathrm{E}-5.31 \mathrm{E} 2.80 \mathrm{E}$ 9.89E $1.58 \mathrm{E} \quad 3.6 \mathrm{E}-$ $\begin{array}{lllllllllllllllllll}26 & 85 & 2 & -07 & -08 & -07 & -08 & -05 & -06 & -08 & -08 & -08 & -07 & 10 & -10 & -11 & -09 & -10 & 11\end{array}$

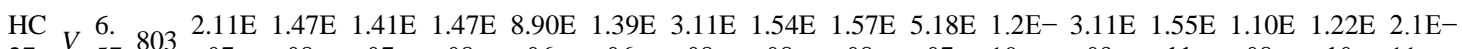

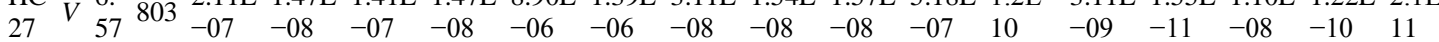
$\mathrm{HC}_{V}$ 6. $144 \quad 8.18 \mathrm{E} \quad 1.30 \mathrm{E} \quad 7.99 \mathrm{E} \quad 3.74 \mathrm{E} \quad 1.46 \mathrm{E} \quad 1.58 \mathrm{E} \quad 3.26 \mathrm{E} \quad 6.75 \mathrm{E} \quad 1.87 \mathrm{E} \quad 4.22 \mathrm{E} \quad 1.4 \mathrm{E}-9.89 \mathrm{E} \quad 1.08 \mathrm{E} 1.43 \mathrm{E} \quad 7.9 \mathrm{E}-5.0 \mathrm{E}-$

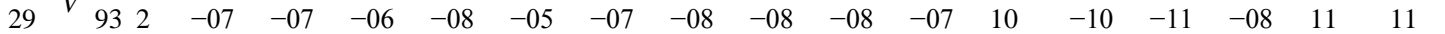
$\mathrm{HC}_{V}{ }^{6}$. $7506.3 \mathrm{E}-5.1 \mathrm{E}-2.14 \mathrm{E} \quad 3.45 \mathrm{E} \quad 6.53 \mathrm{E} \quad 8.44 \mathrm{E} 2.74 \mathrm{E} \quad 1.48 \mathrm{E} 1.61 \mathrm{E} \quad 7.04 \mathrm{E} \quad 1.3 \mathrm{E}-4.44 \mathrm{E} \quad 5.52 \mathrm{E} 1.42 \mathrm{E} \quad 7.9 \mathrm{E}-2.9 \mathrm{E}-$

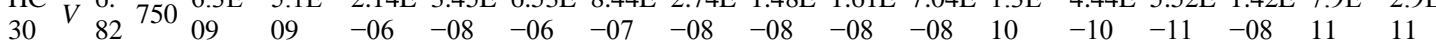
$\mathrm{HC}_{V}$ 6. 117 2.07E $4.60 \mathrm{E} \quad 2.16 \mathrm{E} \quad 2.09 \mathrm{E} \quad 1.84 \mathrm{E} \quad 7.48 \mathrm{E} 3.33 \mathrm{E} \quad 3.46 \mathrm{E} \quad 2.12 \mathrm{E} \quad 9.29 \mathrm{E} \quad 1.24 \mathrm{E} 3.33 \mathrm{E} \quad 1.08 \mathrm{E} \quad 1.53 \mathrm{E} \quad 1.30 \mathrm{E} \quad 6.4 \mathrm{E}-$

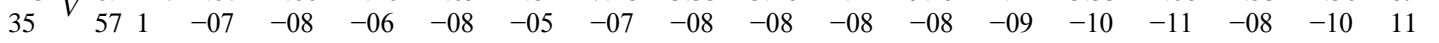
$\mathrm{HC}_{V} 7.1101 .16 \mathrm{E} \quad 1.08 \mathrm{E} \quad 9.71 \mathrm{E} \quad 4.56 \mathrm{E} \quad 5.40 \mathrm{E} \quad 2.91 \mathrm{E} 4.11 \mathrm{E} \quad 4.69 \mathrm{E} \quad 1.97 \mathrm{E} \quad 1.89 \mathrm{E}$.

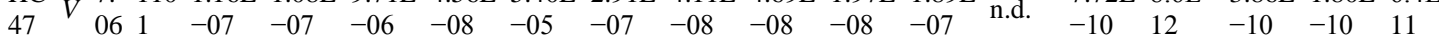

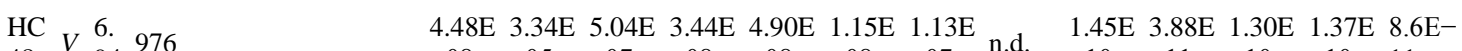

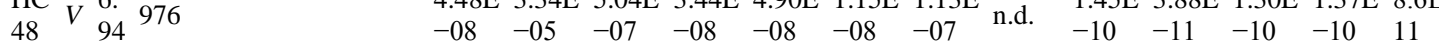

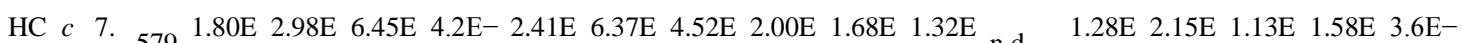

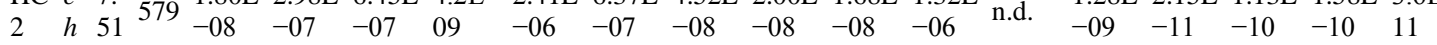

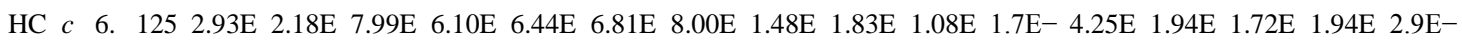
$\begin{array}{llllllllllllllllllll}23 & h & 97 & 0 & -06 & -07 & -08 & -07 & -06 & -07 & -08 & -07 & -07 & -06 & 10 & -10 & -11 & -10 & -10 & 11\end{array}$ HC $c$ 7. ${ }_{598} 9.7 \mathrm{E}-3.30 \mathrm{E} \quad 1.91 \mathrm{E} \quad 8.3 \mathrm{E}-8.20 \mathrm{E} 1.31 \mathrm{E} 2.70 \mathrm{E} \quad 4.0 \mathrm{E}-1.02 \mathrm{E} 6.16 \mathrm{E}$. $8.2 \mathrm{E}-2.97 \mathrm{E} 6.06 \mathrm{E} \quad 5.8 \mathrm{E}-1.4 \mathrm{E}-$

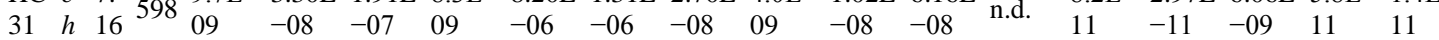
$\mathrm{HC} c$ 7. 143 3.60 $3.36 \mathrm{E}$ 5.63E $1.77 \mathrm{E} 2.64 \mathrm{E} 2.28 \mathrm{E} 5.93 \mathrm{E} \quad 8.17 \mathrm{E} 3.19 \mathrm{E} 1.35 \mathrm{E}$. $3.48 \mathrm{E} 2.37 \mathrm{E} 1.01 \mathrm{E} 3.17 \mathrm{E} 2.9 \mathrm{E}-$ $\begin{array}{llllllllllllllllllll}32 & h & 53 & 9 & -08 & -08 & -07 & -08 & -05 & -06 & -08 & -08 & -08 & -07 & \text { n.d. } & -10 & -11 & -08 & -10 & 11\end{array}$

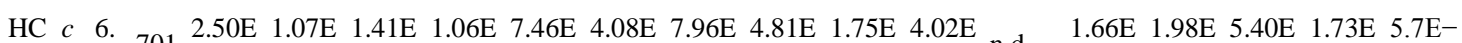

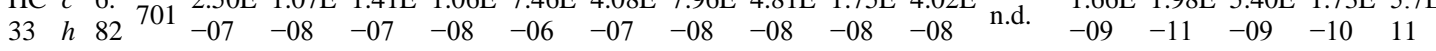

HC $c$ 7. 712 3.50E 7.54E $2.95 \mathrm{E} \quad 1.9 \mathrm{E}-5.23 \mathrm{E} 2.00 \mathrm{E} 3.19 \mathrm{E} 2.29 \mathrm{E} \quad 1.24 \mathrm{E} \quad 5.54 \mathrm{E}$. $1.30 \mathrm{E} \quad 9.1 \mathrm{E}-5.91 \mathrm{E} \quad 8.6 \mathrm{E}-4.3 \mathrm{E}-$

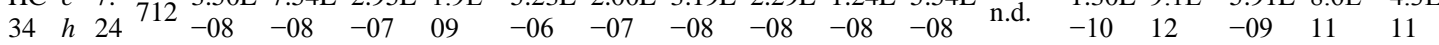

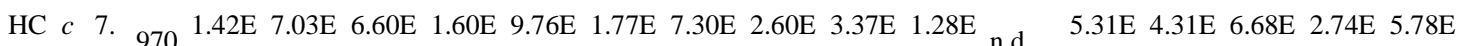

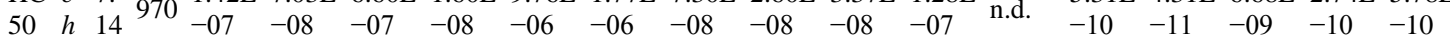
$\mathrm{HC} c$ 7. $1012.20 \mathrm{E} 2.84 \mathrm{E} \quad 4.11 \mathrm{E} \quad 7.6 \mathrm{E}-2.26 \mathrm{E} \quad 1.71 \mathrm{E} 3.00 \mathrm{E} \quad 4.96 \mathrm{E} \quad 1.32 \mathrm{E} \quad 5.31 \mathrm{E}$. $1.93 \mathrm{E} \quad 4.3 \mathrm{E}-7.89 \mathrm{E} \quad 1.15 \mathrm{E} \quad 8.6 \mathrm{E}-$ $\begin{array}{llllllllllllllllllll}52 & h & 29 & 0 & -08 & -07 & -07 & 09 & -05 & -06 & -08 & -08 & -08 & -08 & \text { n.d. } & -10 & 12 & -09 & -10 & 11\end{array}$ $\mathrm{HC}{ }_{K}$ 6. $107 \quad 1.20 \mathrm{E} 2.08 \mathrm{E} \quad 2.13 \mathrm{E} \quad 9.2 \mathrm{E}-2.23 \mathrm{E} \quad 1.85 \mathrm{E} 2.22 \mathrm{E} \quad 3.52 \mathrm{E} \quad 1.57 \mathrm{E} \quad 2.37 \mathrm{E} \quad$ 5.55E $1.72 \mathrm{E} 1.92 \mathrm{E} 1.51 \mathrm{E} \quad 7.1 \mathrm{E}-$

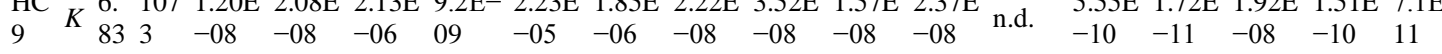


${ }^{\mathrm{HC}}{ }_{K}{ }^{7 .}{ }_{6}{ }_{6}{ }^{2} 1.17 \mathrm{E} \quad 1.27 \mathrm{E} \quad 4.22 \mathrm{E} \quad 1.59 \mathrm{E} \quad 7.81 \mathrm{E} \quad 1.67 \mathrm{E} \quad 2.74 \mathrm{E} \quad 3.96 \mathrm{E} \quad 1.48 \mathrm{E} \quad 1.06 \mathrm{E}$ n.d. $1.98 \mathrm{E} \quad 8.6 \mathrm{E}-9.87 \mathrm{E} \quad 1.87 \mathrm{E} \quad 8.6 \mathrm{E}-$

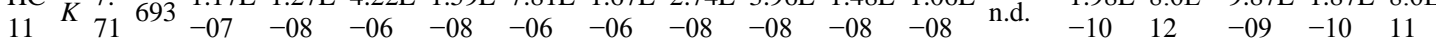

$\mathrm{HC}$ 6. $508 \quad 8.69 \mathrm{E} \quad 4.01 \mathrm{E} \quad 2.95 \mathrm{E} \quad 4.84 \mathrm{E} \quad 7.74 \mathrm{E} \quad 5.16 \mathrm{E} \quad 5.15 \mathrm{E} \quad 5.60 \mathrm{E} \quad 5.51 \mathrm{E} \quad 3.26 \mathrm{E} \quad 2.2 \mathrm{E}-4.97 \mathrm{E} \quad 1.03 \mathrm{E} \quad 8.07 \mathrm{E} \quad 2.38 \mathrm{E} \quad 1.0 \mathrm{E}-$

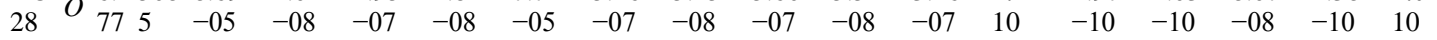

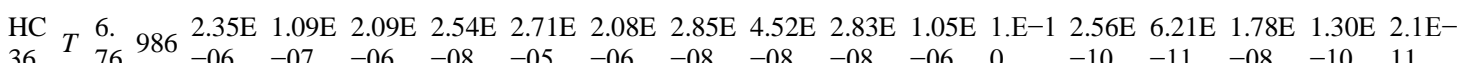

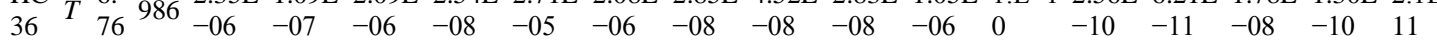

$\mathrm{HC} o$ 6. $102 \quad 1.34 \mathrm{E} \quad 5.0 \mathrm{E}-1.65 \mathrm{E} \quad 7.1 \mathrm{E}-1.03 \mathrm{E} \quad 1.00 \mathrm{E} \quad 5.81 \mathrm{E} \quad 3.13 \mathrm{E} \quad 1.81 \mathrm{E} \quad 5.60 \mathrm{E} \quad 1.2 \mathrm{E}-1.11 \mathrm{E} \quad 5.60 \mathrm{E} \quad 1.94 \mathrm{E} \quad 8.6 \mathrm{E}-2.9 \mathrm{E}-$

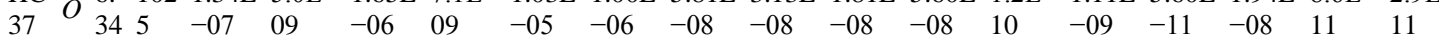

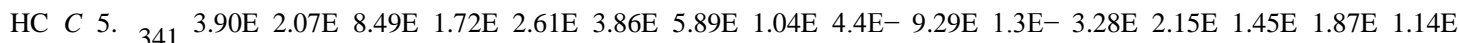

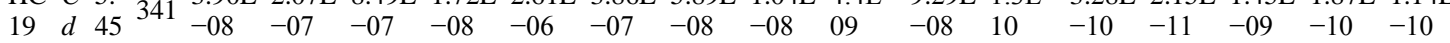

$\mathrm{HC} C 5 .{ }_{23} \quad 6.81 \mathrm{E} 1.09 \mathrm{E} \quad 4.88 \mathrm{E} \quad 1.30 \mathrm{E} \quad 1.23 \mathrm{E} \quad 4.05 \mathrm{E} \quad 4.56 \mathrm{E} \quad 9.0 \mathrm{E}-1.23 \mathrm{E} \quad 3.91 \mathrm{E}$. $1.92 \mathrm{E} \quad 2.59 \mathrm{E} 4.12 \mathrm{E} 1.08 \mathrm{E} 4.92 \mathrm{E}$

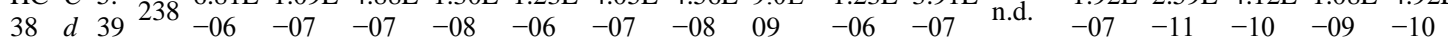

HC $C 5 . \quad 1937.80 \mathrm{E} 1.93 \mathrm{E} \quad 4.51 \mathrm{E} \quad 1.02 \mathrm{E} \quad 1.01 \mathrm{E} \quad 3.90 \mathrm{E} \quad 2.93 \mathrm{E} \quad 5.8 \mathrm{E}-1.53 \mathrm{E} \quad 7.82 \mathrm{E} \quad 1.71 \mathrm{E} \quad 1.85 \mathrm{E} \quad 2.15 \mathrm{E} \quad 7.60 \mathrm{E} \quad 8.14 \mathrm{E} \quad 5.7 \mathrm{E}-$

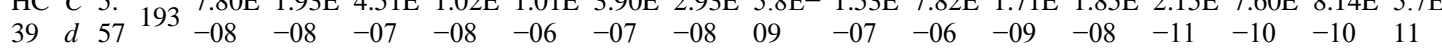
HC $C$ 5. $3206.00 \mathrm{E} \quad 1.28 \mathrm{E} \quad 4.44 \mathrm{E}$ $\begin{array}{lllllll}40 & d & 34 & 320 & -08 & -08 & -07\end{array}$

HC $C 5.2376 .40 \mathrm{E} 1.00 \mathrm{E} \quad 5.72 \mathrm{E}$

$\begin{array}{lllllll}42 & d & 22 & 237 & -07 & -07 & -07\end{array}$

HC $C$ 5. $2605.20 \mathrm{E} 1.26 \mathrm{E} 7.59 \mathrm{E}$

$\begin{array}{lllllll}43 & d & 37 & 260 & -06 & -06 & -07\end{array}$

HC $C$ 5. 286 2.95E 7.13E $8.87 \mathrm{E}$

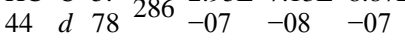

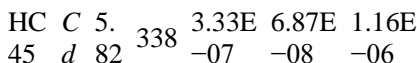

HC $C 5 .{ }_{39}$ 9.70E $5.12 \mathrm{E} \quad 1.06 \mathrm{E} \quad 1.32 \mathrm{E} \quad 5.32 \mathrm{E} \quad 4.74 \mathrm{E} \quad 9.8 \mathrm{E}-2.59 \mathrm{E} \quad 2.05 \mathrm{E} \quad 9.7 \mathrm{E}-2.76 \mathrm{E} \quad 4.3 \mathrm{E}-1.60 \mathrm{E} \quad 2.30 \mathrm{E} \quad 1.57 \mathrm{E}$

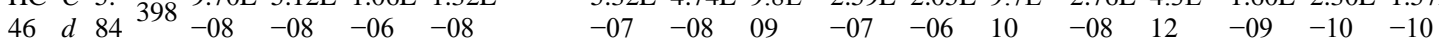

Table 4b. October 2001. Trace element concentrations (mol/L) in waters. TDS as mg/L. n.d.: not detected. V: Vanur, ch: charnockite, Cd: Cuddalore, and O: Ottai aquifer.

\begin{tabular}{|c|c|c|c|c|c|c|c|c|c|c|c|c|c|c|c|c|}
\hline el & & $\begin{array}{l}\mathbf{p} \\
\mathbf{H}\end{array}$ & & $\mathbf{F e}$ & Mn & $\mathbf{L i}$ & $3 e$ & B & b & Sr & P & Al & Ge & As & Se & \\
\hline$H F$ & $V$ & $\begin{array}{l}6 . \\
90\end{array}$ & 96 & $d$ & & & & & & & & & & & & \\
\hline $\mathrm{IE}$ & . & $\begin{array}{l}7 . \\
00\end{array}$ & 81 & n.d. & $\begin{array}{l}3.3 \mathrm{E}- \\
09\end{array}$ & $\begin{array}{l}9.90 \mathrm{E} \\
-07\end{array}$ & n.d. & $\begin{array}{l}7.11 \mathrm{E} \\
-06\end{array}$ & $\mathrm{E}$ & $\begin{array}{l}4.30 \mathrm{E} \\
-06\end{array}$ & & & $\begin{array}{l}3.88 \mathrm{E} \\
-09\end{array}$ & $\begin{array}{l}3.57 \mathrm{E} \\
-08\end{array}$ & $6 \mathrm{E}$ & $\begin{array}{l}3.10 \mathrm{E} \\
-08\end{array}$ \\
\hline & $V$ & $\begin{array}{l}7 . \\
03\end{array}$ & $\begin{array}{l}6 \\
2\end{array}$ & n.d. & & & & & & & & & & & & $\begin{array}{l}2.20 \mathrm{E} \\
-08\end{array}$ \\
\hline $\mathrm{HE}$ & ( & $\begin{array}{l}6 . \\
95\end{array}$ & 85 & n.d. & & & & & & & & & & & & $\begin{array}{l}2.77 \mathrm{E} \\
-08\end{array}$ \\
\hline $\begin{array}{l}\mathrm{HE} \\
29\end{array}$ & V & $\begin{array}{l}6 . \\
95\end{array}$ & $\begin{array}{l}14 \\
48\end{array}$ & $\begin{array}{l}1.28 \mathrm{E} \\
-06\end{array}$ & & & & & & & & & & & & \\
\hline E & V & $\begin{array}{l}6 . \\
93\end{array}$ & $\begin{array}{l}12 \\
02\end{array}$ & $\begin{array}{l}4.48 \mathrm{E} \\
-07\end{array}$ & & & & & & & & $\begin{array}{l}2 . \\
-c\end{array}$ & & FE & & $\begin{array}{l}2.00 \mathrm{E} \\
-08\end{array}$ \\
\hline $\mathrm{HF}$ & $y^{\prime}$ & 7. & 97 & n.d & & & & & & & & & & & & $\begin{array}{l}1.28 \mathrm{E} \\
-08\end{array}$ \\
\hline & $\begin{array}{l}c \\
h\end{array}$ & $\begin{array}{l}6 . \\
98\end{array}$ & $\begin{array}{l}65 \\
2\end{array}$ & n.d. & & & $11 \mathrm{~F}_{-}$ & & & & & & $\begin{array}{l}8.7 \mathrm{E}- \\
10\end{array}$ & & & $\begin{array}{l}2.27 \mathrm{E} \\
-08\end{array}$ \\
\hline & $\begin{array}{l}c \\
h\end{array}$ & $\begin{array}{l}7 . \\
19\end{array}$ & 15 & n.d. & & & d & & n.d. & & & & & & & $\begin{array}{l}3.23 \mathrm{E} \\
-08\end{array}$ \\
\hline & $\begin{array}{l}c \\
h\end{array}$ & $\begin{array}{l}7 . \\
52\end{array}$ & $\begin{array}{l}67 \\
0\end{array}$ & $\begin{array}{l}3.17 \mathrm{E} \\
-07\end{array}$ & $\begin{array}{l}1.96 \mathrm{E} \\
-07\end{array}$ & & & & & & & & & $\mathrm{E}$ & & $3.36 \mathrm{E}$ \\
\hline $\mathrm{HE}$ & $\begin{array}{l}c \\
h\end{array}$ & $\begin{array}{l}7 . \\
17\end{array}$ & 70 & n.d. & $\begin{array}{l}1.83 \mathrm{E} \\
-08\end{array}$ & $\begin{array}{l}5.8 \mathrm{E}- \\
08\end{array}$ & $2.2 \mathrm{E}-$ & $\begin{array}{l}8.21 \mathrm{E} \\
-06\end{array}$ & & & & & & & & $\begin{array}{l}2.85 \mathrm{E} \\
-08\end{array}$ \\
\hline $\begin{array}{l}\mathrm{HE} \\
50\end{array}$ & $\begin{array}{l}c \\
h\end{array}$ & 6 & 10 & n.a. & $\begin{array}{l}4.64 \mathrm{E} \\
-08\end{array}$ & $\begin{array}{l}7.70 \mathrm{E} \\
-07\end{array}$ & 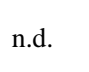 & $\begin{array}{l}6.24 \mathrm{E} \\
-06\end{array}$ & & & & & & & & $\begin{array}{l}3.49 \mathrm{E} \\
-08\end{array}$ \\
\hline $\begin{array}{l}\mathrm{HE} \\
52\end{array}$ & $\begin{array}{l}c \\
h\end{array}$ & $\begin{array}{l}7 . \\
15\end{array}$ & 13 & n.d. & $\begin{array}{l}1.20 \mathrm{E} \\
-06\end{array}$ & $\begin{array}{l}4.17 \mathrm{E} \\
-07\end{array}$ & $\begin{array}{l}4.2 \mathrm{E}- \\
09\end{array}$ & $\begin{array}{l}5.05 \mathrm{E} \\
-06\end{array}$ & & & & & $\begin{array}{l}5.2 \mathrm{E}- \\
10\end{array}$ & & & $\begin{array}{l}3.63 \mathrm{E} \\
-08\end{array}$ \\
\hline $\begin{array}{l}\mathrm{HE} \\
19\end{array}$ & $\begin{array}{l}C \\
d\end{array}$ & 5. & $\begin{array}{l}38 \\
1\end{array}$ & .d. & $\begin{array}{l}1.54 \mathrm{E} \\
-07\end{array}$ & $\begin{array}{l}1.13 \mathrm{E} \\
-06\end{array}$ & $2.6 \mathrm{E}-$ & $\begin{array}{l}9.28 \mathrm{E} \\
-06\end{array}$ & & & & & & $\begin{array}{l}5.57 \mathrm{E} \\
-09\end{array}$ & & $\begin{array}{l}4.25 \mathrm{E} \\
-08\end{array}$ \\
\hline
\end{tabular}




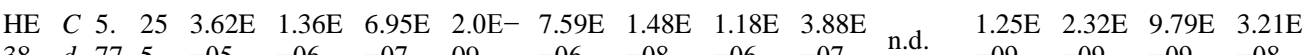

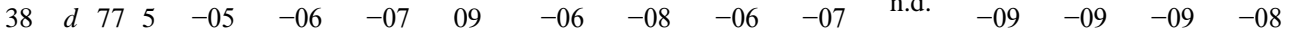

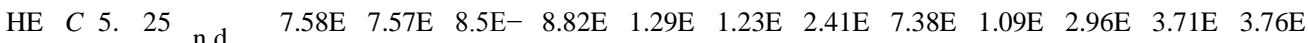

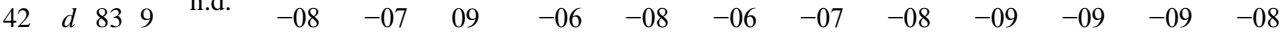

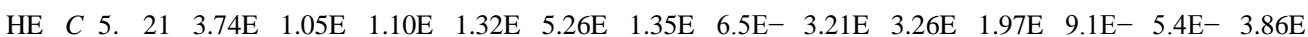

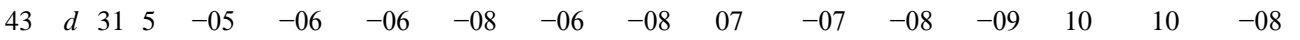

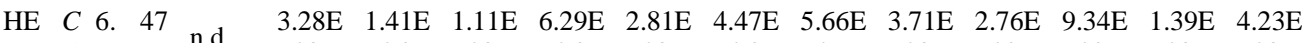

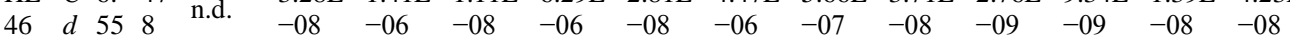

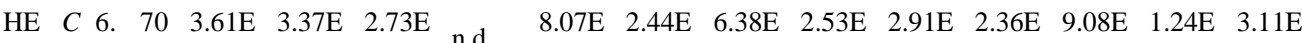
$\begin{array}{lllllllllllllllll}53 & d & 80 & 4 & -08 & -07 & -06 & \text { n.d. } & -06 & -08 & -06 & -07 & -08 & -09 & -09 & -08 & -08\end{array}$

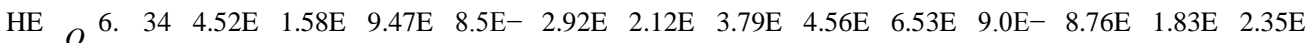

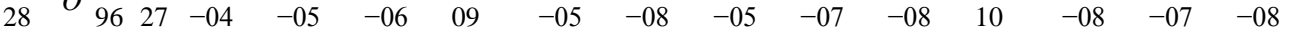
$\mathrm{HE} O{ }^{6 .} 87$ n.d. $8.2 \mathrm{E}-2.21 \mathrm{E} \quad 1 . \mathrm{E}-1 \quad 1.30 \mathrm{E} \quad 7.4 \mathrm{E}-\quad 7.76 \mathrm{E} \quad 7.06 \mathrm{E} \quad 2.41 \mathrm{E} \quad 4.1 \mathrm{E}-\quad 2.41 \mathrm{E} \quad 3.5 \mathrm{E}-\quad 3.27 \mathrm{E}$

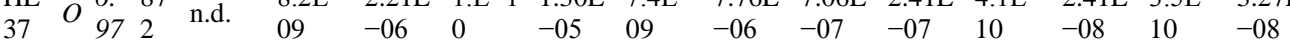

$\begin{array}{llllllllllllll}\text { Labe } & \mathrm{Ti} & \mathrm{V} & \mathrm{Cr} & \mathrm{Co} & \mathrm{Ni} & \mathrm{Cu} & \mathrm{Zn} & \mathrm{Mo} & \mathrm{Cd} & \mathrm{Pb} & \mathrm{Th}\end{array}$

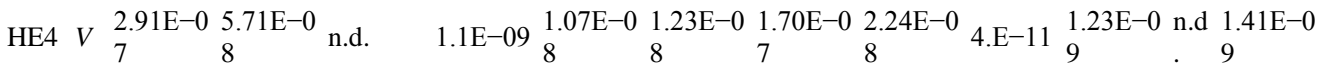

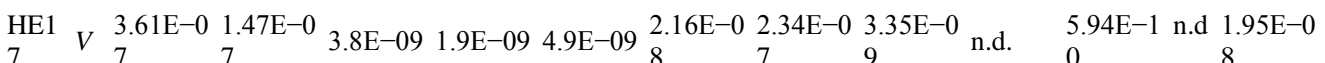

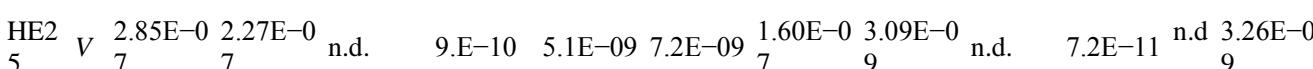
HE2 $V \quad 2.55 \mathrm{E}-0 \quad 2.37 \mathrm{E}-0 \quad 2.3 \mathrm{E}-09 \quad 1.8 \mathrm{E}-09 \quad \begin{array}{llllllll}1.39 \mathrm{E}-0 & 1.64 \mathrm{E}-0 & 4.89 \mathrm{E}-0 & 1.31 \mathrm{E}-0 & 1.6 \mathrm{E}-1 & 1.05 \mathrm{E}-0 & \text { n.d } & 2.03 \mathrm{E}-0\end{array}$

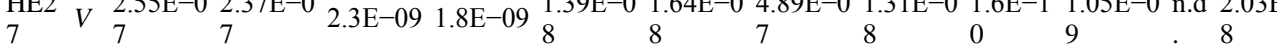

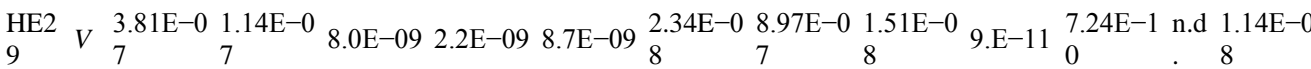

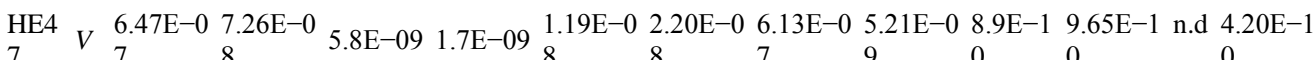

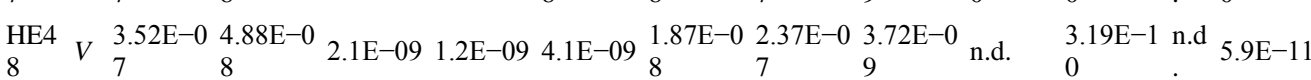

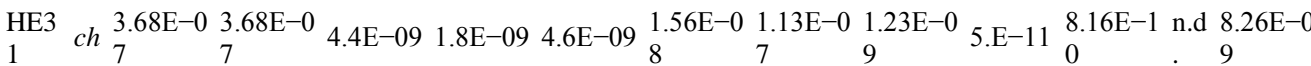

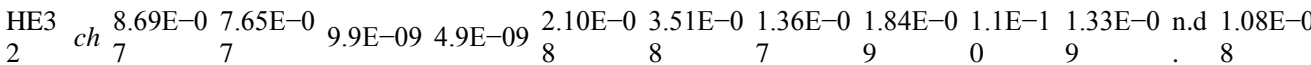

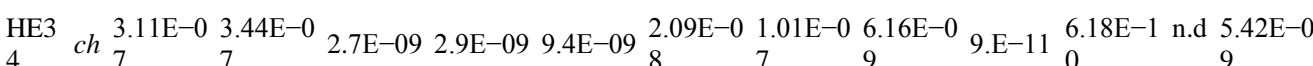

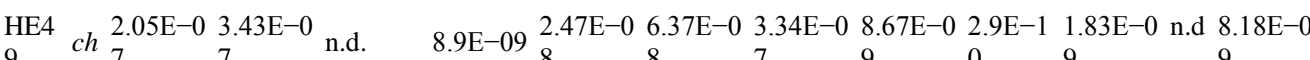

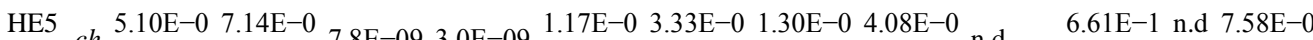
$\begin{array}{llllllllll}0 & \operatorname{ch} & 5.10 \mathrm{E}-0 & 7.14 \mathrm{E}-0 & 7.8 \mathrm{E}-09 & 3.0 \mathrm{E}-09 & 1.17 \mathrm{E}-0 & 3.33 \mathrm{E}-0 & 1.30 \mathrm{E}-0 & 4.08 \mathrm{E}-0 \\ & 7 & & 8 & 8 & 7 & 9 & \text { n.d. } & 0 & .9\end{array}$

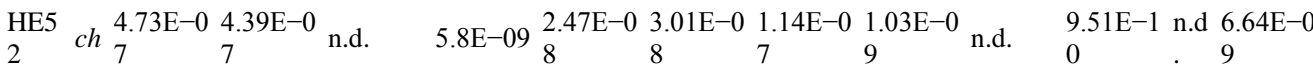

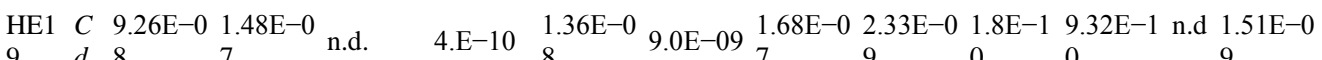

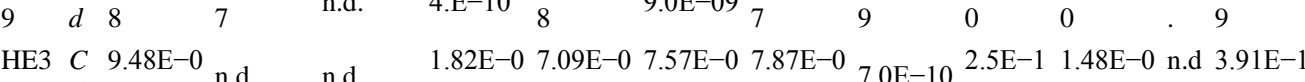
$\begin{array}{lllllllllllll}8 & d & 8 & \text { n.d. } & \text { n.d. } & 8 & 8 & 7 & 7 & 7.0 \mathrm{E}-10 & 0 & 9 & 0\end{array}$ HE4 $C \quad 8.39 \mathrm{E}-0 \quad 5.67 \mathrm{E}-0 \quad 1.83 \mathrm{E}-0 \quad 5 . \mathrm{E}-10{ }^{1.39 \mathrm{E}-0} 7.6 \mathrm{E}-099^{2.05 \mathrm{E}-0} 2.4 \mathrm{E}-10{ }^{1.2 \mathrm{E}-1}$ n.d. n.d $1.47 \mathrm{E}-1$ $\begin{array}{lllllllllllll}2 & d & 8 & 8 & 8 & 5 . \mathrm{E}-10 & 8 & 7.6 \mathrm{E}-09 & 7 & 2.4 \mathrm{E}-10 & 0 & \text { n.d. } & .\end{array}$

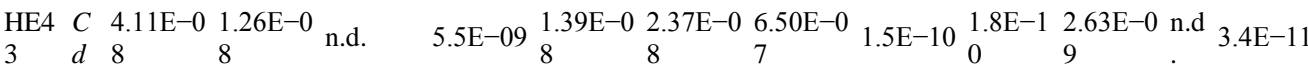

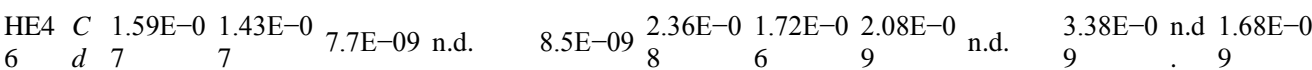
HE5 $C \quad 4.03 \mathrm{E}-0 \quad 2.68 \mathrm{E}-0$ n.d. $\quad 2.6 \mathrm{E}-09 \quad 4.4 \mathrm{E}-09 \quad 1.70 \mathrm{E}-0 \quad 1.16 \mathrm{E}-0 \quad 3.88 \mathrm{E}-0$ n.d. $\quad 2.32 \mathrm{E}-1$ n.d $7.52 \mathrm{E}-1$ $\begin{array}{llllllll}3 & d & 7 & 8 & 7 & 9 & 0 & 0 \\ 0\end{array}$

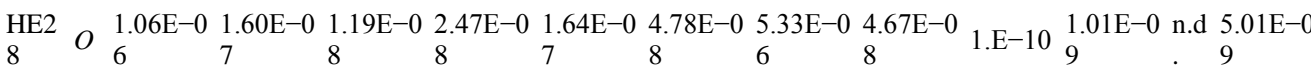

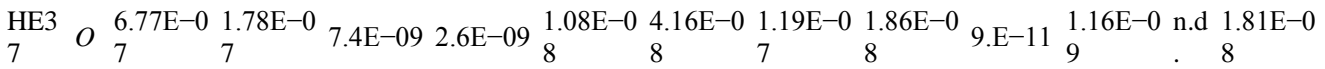


Strontium distribution followed the water-rock interaction pattern (Fig. 3d) in all the aquifers, except in \#47 which exhibited a particularly high Sr content. Strontium can substitute for $\mathrm{Ca}$ in plagioclase, hornblende and carbonate minerals. Calcium and $\mathrm{Sr}$ can also substitute for $\mathrm{K}$ in micas and alkali feldspars. In the charnockite, Sr was probably mainly released from plagioclase (Bau et al., 2004). In the Vanur sandstone, Sr was probably released from detritic plagioclase and alkali feldspar, and from carbonate cement dissolution. Strontium distribution suggested that the Sr-bearing minerals were more Sr-enriched in the Vanur aquifer than in the charnockite aquifer (Fig. 4a). Due to Sr incorporation during calcite precipitation (e.g. Tang et al., 2008) and to its structural properties (Lucas-Girot et al., 2007), the Sr-rich mineral in Vanur is likely to be carbonate cement. In the Vanur aquifer, the following correlation (for the January and October 2001 series) can be calculated, omitting HC35 which was suspected to have an input from another aquifer (Gassama et al., 2011; input from Ottai-like water (HC37), see also results for $\mathrm{Ba}$ ):

$[\mathrm{Sr}]=2.43 \times 10^{-2}[\mathrm{Ca}]-2.44 \times 10^{-5} \quad n=22 \quad R^{2}=0.521$ 

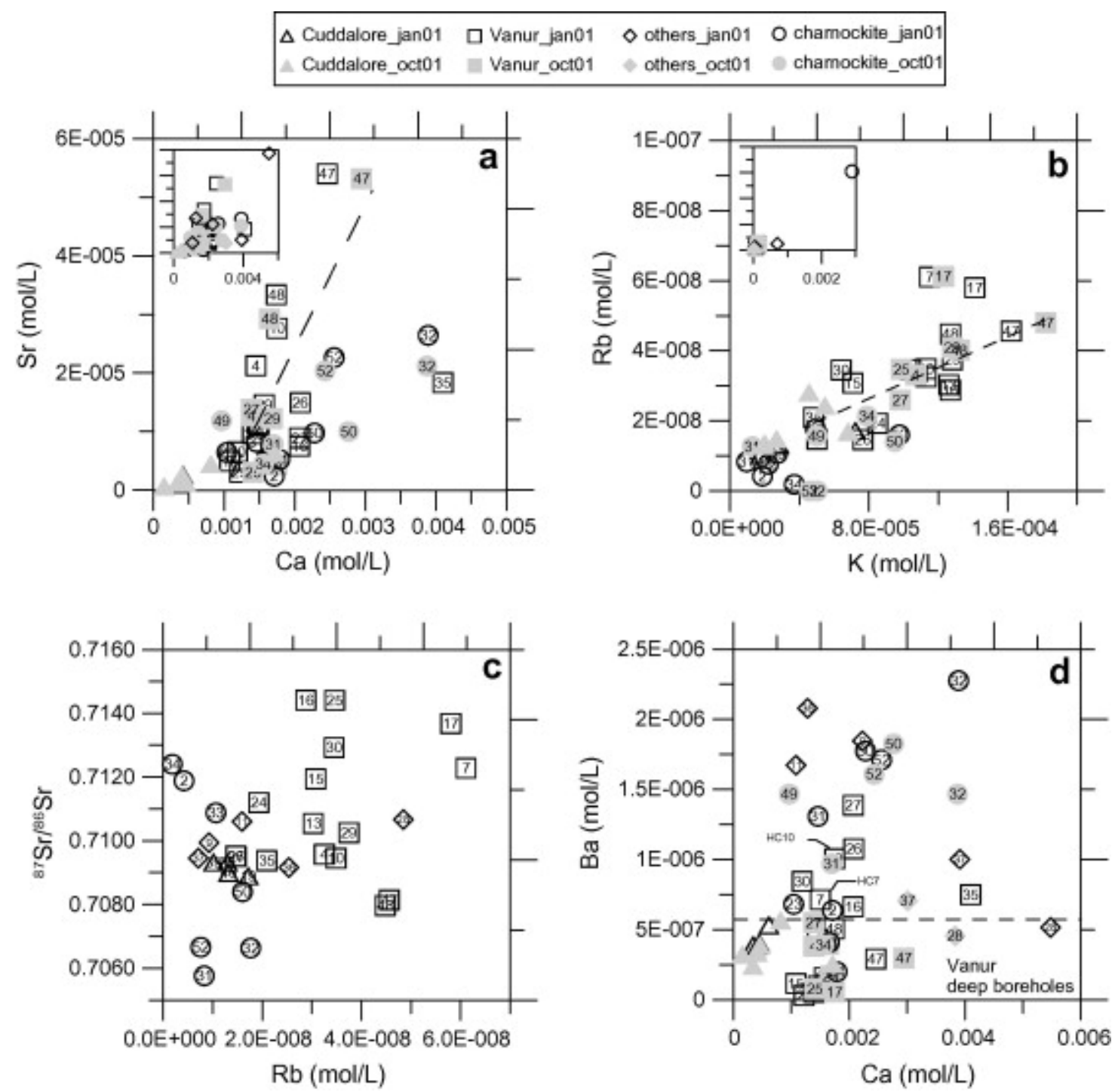

Fig. 4. Distribution of: (a) Sr versus Ca, (b) Rb versus K, (c) ${ }^{87} \mathrm{Sr} /{ }^{86} \mathrm{Sr}$ ratio versus $\mathrm{Rb}$, and (d) Ba versus Ca in water samples (molar concentrations except ${ }^{87} \mathrm{Sr} /{ }^{86} \mathrm{Sr}$ ratio in \%o).

The low correlation coefficient is probably due to the low degree of mixing with other aquifers and because $\mathrm{Sr}$ can originate from different minerals.

Strontium was not a suitable tracer to distinguish between the aquifers. Waters from the Vanur and from the charnockite aquifers exhibited a similar pattern (Figs. $\underline{3} \mathrm{~d}$ and $\underline{4}$ a) although the Vanur rocks were Sr-depleted compared to charnockite (Table 3).

Rubidium substitutes for $\mathrm{K}$ in both biotite and $\mathrm{K}$-feldspar. Distribution of $\mathrm{Rb}$ with that of $\mathrm{K}$ followed the expected pattern (Fig. 4b). However, \#7, a deep borehole (210 $\mathrm{m}$ deep), and \#17, in the recharge area, exhibited an exceptionally high concentration of $\mathrm{K}$ compared to other Vanur waters (Table $4 \mathrm{a}$ and Table $4 \mathrm{~b}$ ) and a higher $\mathrm{Rb} / \mathrm{K}$ ratio. The high ${ }^{87} \mathrm{Sr} /{ }^{86} \mathrm{Sr}$ ratio and the high Rb contents (Fig. 4c) of \#7 and \#17 could be explained by contamination from fertilizer input such as Fert2 (mainly composed of $\mathrm{KCl},{ }^{87} \mathrm{Sr} /{ }^{86} \mathrm{Sr}$ ratio $=0.714050$ ) (Gassama 
et al., 2011). Vanur waters were richer in $\mathrm{Rb}$ than those from charnockite (Table 3 ) in line with the contrasting distribution in host rocks. This apparent correlation between rocks and waters was not observed in the Cuddalore aquifer. In the Vanur aquifer, the correlation (for January and October 2001 series) can be calculated as follows, omitting \#7 and 17:

$$
[\mathrm{Rb}]=2.21 \times 10^{-4}[\mathrm{~K}]+8.71 \times 10^{-9} \quad n=20 \quad R^{2}=0.637
$$

The potential location of $\mathrm{Ba}$ in minerals is the same as for $\mathrm{Sr}$. In the water samples studied, $\mathrm{Ba}$ distribution was independent of $\mathrm{K}$, but followed that of $\mathrm{Ca}$ (Fig. 4d). As in the rocks, waters from the charnockite aquifer were Ba-enriched compared to those from the Vanur and Cuddalore aquifers (Table 3, Fig. 4d). Even the deepest Vanur boreholes exhibited a lower Ba content than charnockite boreholes. Barium, therefore, appears to originate mainly from weathering of plagioclase (and to a lesser degree of hornblende). By plotting Ba against Li distribution it is possible to differentiate between charnockite and Vanur waters (Fig. 5a) even if some Vanur boreholes appear to have mixed waters. However, waters from the carbonate reservoirs display a similar pattern to that of the charnockite group (Fig. 5a). Thus, 3 types of water can be distinguished (Fig. 5a): (i) "superficial", i.e. waters from unconfined aquifers with high $\mathrm{Ba}$ and low Li concentrations (charnockite, Kaddaperikuppam and Turovai), (ii) shallow to deep waters from confined aquifers with low Ba and high Li concentration (Ottai and Vanur), and (iii) waters from the Cuddalore aquifer with low $\mathrm{Ba}$ and Li concentrations. As previously reported (Gassama et al., 2011), \#53 (Cuddalore) appears to have a significant input from the Vanur (Fig. 5a). In the Vanur (Fig. 5b), the marked input of superficial water recorded in \#16 and \#30 was expected, but that recorded for \#26, 27, 35, 7 and 10 (confined aquifer) was not. This observation suggests hydraulic connections between some Vanur boreholes and the above aquifers. Because of the low relief and the traditional rainwater harvesting through shallow tanks (D’Ozouville et al., 2006), running waters supplying the swamp came mainly from the charnockite outcrop area. Infiltration of swamp waters was suspected in \#7 and 10 from major elements in January 1999 and October 2000, and in January 1999 and October 2001, respectively (Gassama et al., 2011). In contrast to major elements, the swamp signature seems to remain measurable for Ba in January 2001. The recorded fertilizer input in \#7, from $\mathrm{Rb}$ and the ${ }^{87} \mathrm{Sr} /{ }^{86} \mathrm{Sr}$ ratio, could be ascribed to an infiltration of swamp waters mixed with irrigation waters. The input signature can sometimes fall rapidly as observed in \#27 between January 2001 and October 2001 (Fig. 5b). 

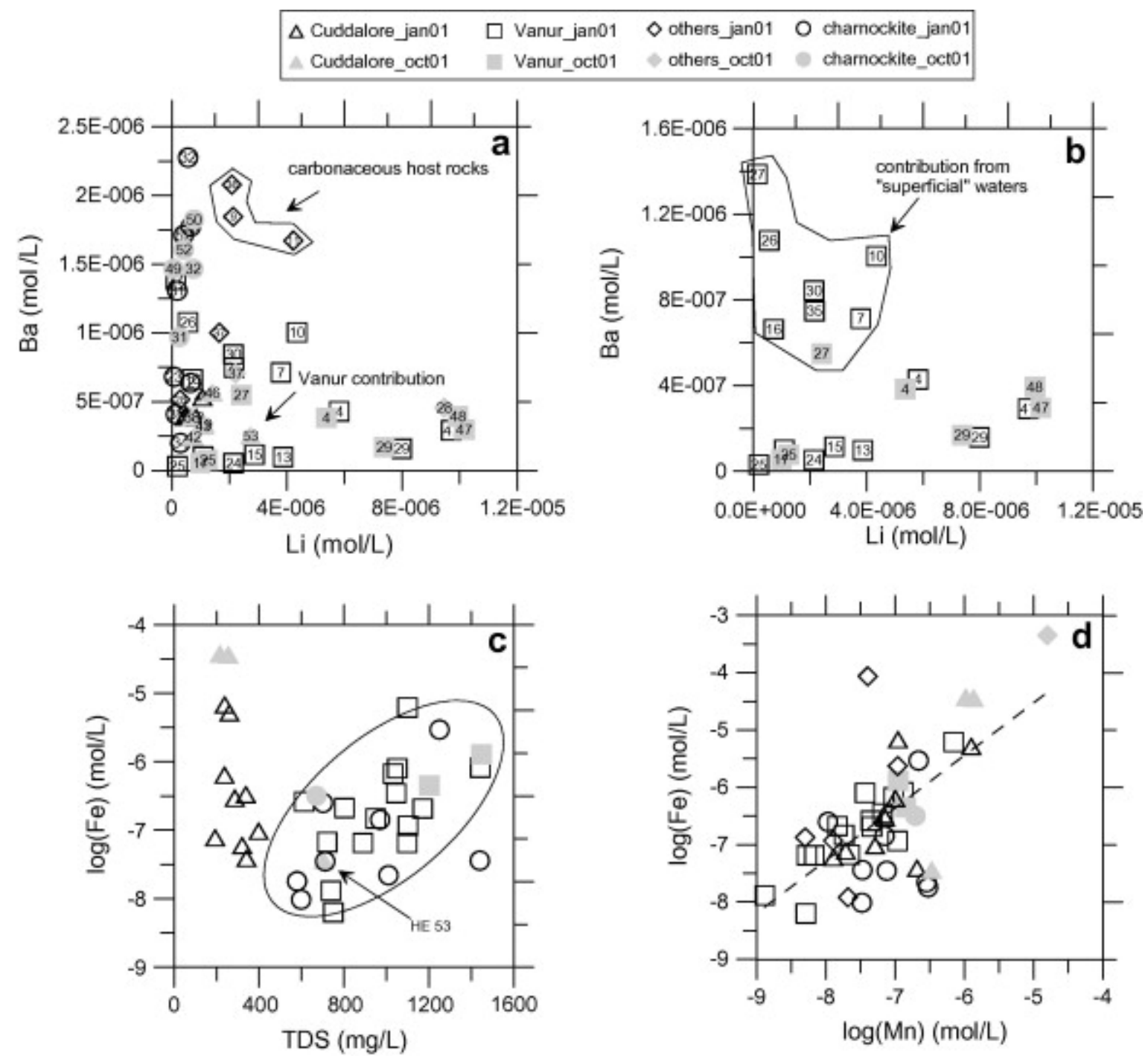

Fig. 5. Distribution of: (a) Ba versus Li in water samples, (b) Ba versus Li, and (c) $\log (\mathrm{Fe}$ ) versus TDS in the Vanur aquifer, (d) $\log (\mathrm{Fe})$ versus $\log (\mathrm{Mn})$ in water samples (molar concentrations).

For Be, in contrast to rock analyses (Table 3), water samples did not display any difference between the aquifers (Table $4 \mathrm{~b}$ ). Concentrations of this element remained low and within the same range for all the samples. The chemical properties of Be are closer to those of $\mathrm{Al}$ than to those of the alkaline earth elements (Greenwood and Earnshow, 1997). This could explain the difference observed.

Alkali and alkaline earth elements are very soluble and are not sensitive to the redox state of the solution. Their input to solution mainly depends on the available stock present in the host rock and on the reaction time between water and rock. The rate of release of one trace element may vary considerably depending on the bearing mineral and its dissolution characteristics.

In the water samples studied, $\mathrm{Rb}$ appears to originate from the same minerals in all the aquifers, but $\mathrm{Li}$ and $\mathrm{Sr}$ in the Vanur and charnockite aquifers could originate from different minerals. The available stock of Be was too low to lead to different concentrations in solution, and it, therefore, cannot be used as a discriminating tracer. The difference between the 
weathering properties of Li-bearing minerals (biotite, other micas and pyroxenes) was sufficiently significant to distinguish between aquifers, but this was not the case for Sr. The main factor explaining the differences observed for Ba appears to be the available stock of the parent rock. Thus, of the alkali and alkaline earth metals, only Li and Ba can be used to characterize the aquifers in this study. The trace element/major element ratios recorded in waters were systematically inferior to ratios measured in the host rock (Table 5). This result was expected due to the incongruent mineral dissolution.

Table 5. $\mathrm{Li} / \mathrm{Na}, \mathrm{Sr} / \mathrm{Ca}, \mathrm{Rb} / \mathrm{K}$ and $\mathrm{Ti} / \mathrm{Ca}$ ratio recorded in waters and host rock of the Vanur aquifer.

\begin{tabular}{ll}
\multirow{2}{*}{ Ratio $(\mathbf{m o l} / \mathbf{m o l})$} & \multicolumn{2}{c}{ Vanur aquifer } \\
\cline { 2 - 2 } & Water Host rock \\
$\mathrm{Li} / \mathrm{Na}$ & $9.2 \times 10^{-4} 0.38$ \\
$\mathrm{Sr} / \mathrm{Ca}$ & $2.4 \times 10^{-2} 4.7 \times 10^{-2}$ \\
$\mathrm{Rb} / \mathrm{K}$ & $2.7 \times 10^{-4} 2.7 \times 10^{-2}$ \\
$\mathrm{Ti} / \mathrm{Ca}$ & $2.5 \times 10^{-4} 0.51$
\end{tabular}

\subsection{Transition elements, and Ga, Ge, As, Se}

This group comprises redox-sensitive elements whose solubility mainly depends on the redox characteristics of water (Stumm and Morgan, 1970). Low circulation and/or confined parts of these aquifers may show anoxic conditions. Iron and $\mathrm{Mn}$ are the most abundant elements of this group, and their oxides control the solubility of most trace elements (e.g. Jenne, 1968, [Salomons and Forstner, 1984], [Dzombak and Morel, 1990] and [Ponthieu et al., 2006]). Iron and $\mathrm{Mn}$ (in the dissolved phase) exhibited a wide range of concentrations (Table 4a and Table 4b): from below detection limit to $4.52 \times 10^{-4} \mathrm{~mol} / \mathrm{L}$ for Fe; from below detection limit to $1.58 \times 10^{-5} \mathrm{~mol} / \mathrm{L}$ for Mn. Borehole \#28 (the Ottai aquifer) exhibited the highest concentrations. The redox potential may reduce along the flow path and as the water travels deeper the solution may become enriched in dissolved Fe and Mn. This pattern was observed for all the aquifers (Fig. 5c) except for the Cuddalore, which was characterized by Fe- and Mn-enriched waters (Table 4a and Table 4b). This result was unexpected for a superficial aquifer with high transmissivity. This redox window can only be explained by the degradation of organic matter occurring in the soils and consuming $\mathrm{O}_{2}$ during the infiltration of water. This respiration signature was also noticed from the high content of carbonate species (Gassama et al., 2011). A weak correlation between Fe and $\mathrm{Mn}$ was found in all the aquifers (for January and October 2001 series) (Fig. 5d) as follows:

$$
\log ([\mathrm{Fe}])=0.92 \log ([\mathrm{Mn}])+0.058 \quad n=44 \quad R^{2}=0.415
$$

In contrast to what is generally observed in superficial waters, no correlation between Fe or $\mathrm{Mn}$ and any trace elements was observed. This lack of relationship could be attributed to a modification of the redox state during pumping, when air bubble cavitations in the pump body oxidize the solution. Each element reacts according to its specific redox potential and oxidation rate. Therefore, any relationships between elements in the aquifer would have been erased during pumping. 
Within this group of elements, Ti, As and Sc exhibited interesting patterns (Fig. 6). Sodium and $\mathrm{Ca}$ showed a positive correlation with Ti. For Na, 3 types of water can be distinguished (Fig. 6a): (i) "recharge" (Cuddalore, Vanur and low TDS charnockite waters), (ii) Vanur, and (iii) high TDS charnockite waters. \#47 seemed to have an input from another aquifer. Calcium and Ti were correlated throughout the aquifer (Fig. 6b). For the October 2001 series:

$$
[\mathrm{Ca}]=4.04 \times 10^{3}[\mathrm{Ti}]+2.03 \times 10^{-4} \quad n=21 \quad R^{2}=0.957
$$
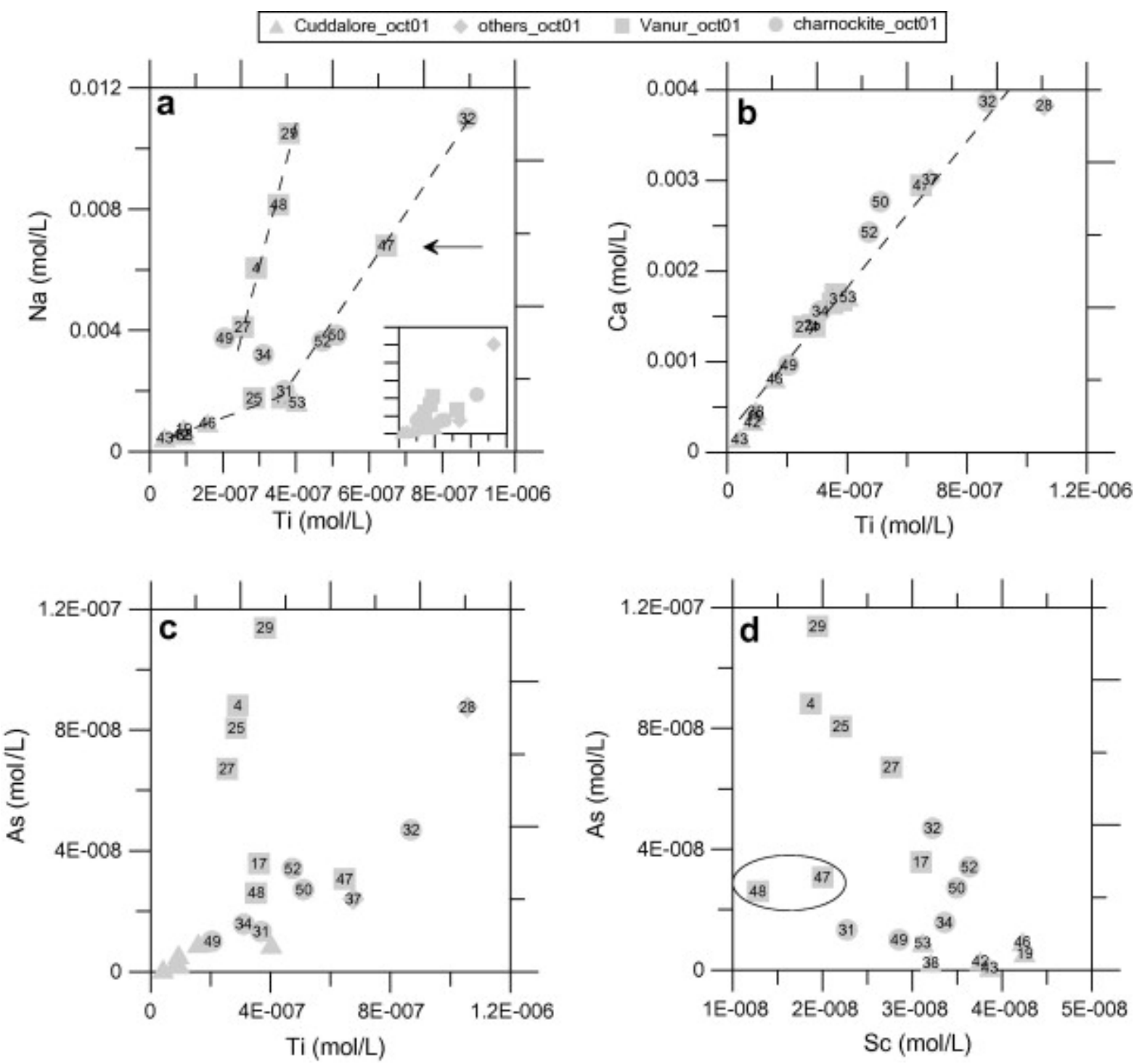

Fig. 6. Distribution of: (a) Na versus Ti, (b) Ca versus Ti, (c) As versus Ti, and (d) As versus Sc in water samples from October 2001 (molar concentrations).

Two main parameters regulate the concentrations of elements such as Ti in water: available stock in rock-forming minerals, and water-rock reaction rate. As expected, analyses of whole 
rocks (Table 2) revealed higher levels of $\mathrm{Ti}$ in the Vanur and Cuddalore sandstones than in charnockite. In charnockite, Ti-bearing minerals were observed to be rutile crystals on plagioclase cleavage planes (Fig. 7). In the two sandstones, Ti was still present in detrital parent material and was also observed as rutile and sphene in the Cuddalore. Differences observed in Vanur and charnockite waters (Fig. 6a) can be attributed to the nature of the feldspar from which the $\mathrm{Na}$ and $\mathrm{Ca}$ originated. As feldspar weathering increases with $\mathrm{Ca}$ content, Vanur sandstone is Ca-feldspar-depleted in comparison with the charnockite, but it is enriched in alkali feldspars, which are not associated with Ti-bearing minerals. The available stock of $\mathrm{Na}$ was higher in the Vanur aquifer formation than in the charnockite. However, because $\mathrm{Na}$ is a major element, its input in water is also regulated by the electroneutrality of the solution. As a result, $\mathrm{Na}$ and $\mathrm{Ti}$ distribution differs in the Vanur and charnockite aquifers (Fig. 6a): Na concentrations in the two aquifers were within the same range, but the charnockite rocks were richer in Ti-bearing plagioclase. As expected, the Ti/Ca ratio recorded in waters was inferior to the ratio measured in the host rock (Table 5).

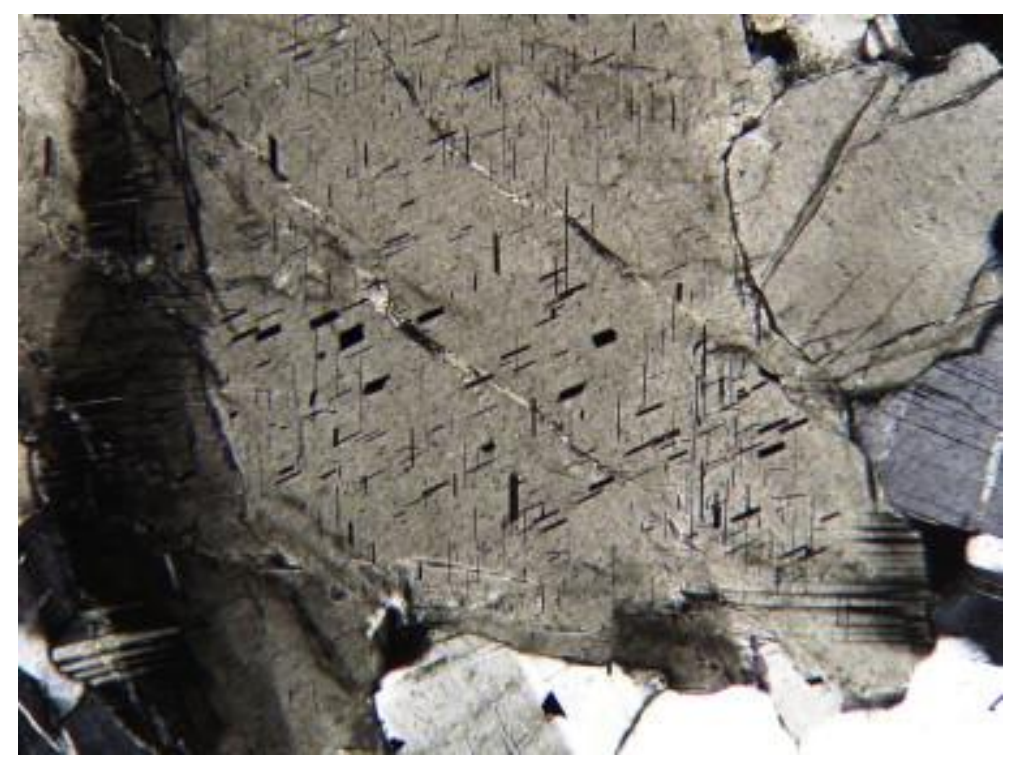

Fig. 7. Example of rutile inclusions in charnockite plagioclase (on cleavage planes). The thin section length measures about $3.2 \mathrm{~mm}$.

Titanium is a low-mobility element, but examples of Ti mobility have been reported in some saprolites under equatorial (Gardner, 1980) and temperate (Chiquet et al., 2000) climates. This mobility can be related to specific conditions such as high concentrations of organic acids (Colin et al., 1993).

Of the redox-sensitive elements, only As appears to record the redox condition of the aquifers (Fig. 6c and d), the deepest boreholes (see Table 1 in Gassama et al., 2011) exhibiting the highest As concentrations. The boreholes can be differentiated by comparing the distribution of As and Sc concentrations (Fig. 6d), which revealed that \#47 and 48 were mixed with oxic or low-As-containing waters. This apparently "conservative" behavior (depending on sampling conditions) was recorded in some shallow and deep aquifers (Dhar et al., 2008), where Fe and Mn distributions over time were erratic, whereas As exhibited a regular 
seasonal distribution. Arsenic(III) oxidation by $\mathrm{O}_{2}$ is slow (Eary and Schramke, 1990 and [Kuhn and Sigg, 1993]). A half-life of around 4-9 days in air-saturated water (pseudo first-order reaction) with low Fe contents and $\mathrm{pH}$ between 7.6 and 8.5 has been measured (Kim and Nriagu, 2000). This half-life depends on Fe content because of removal of As by adsorption on $\mathrm{Fe}(\mathrm{OH})_{3}$ during oxidation.

Results for this group of elements illustrate the difficulty in preserving redox conditions when sampling water from boreholes, which have not been designed for experimental studies. In experimental boreholes, it is possible to measure the aquifer redox potential (Grenthe et al., 1992) and even to preserve species when sampling shallow or deep aquifers (Schürch et al., 2004) through the use of packers and $\mathrm{N}_{2}$ pressure (Roy and Fouillac, 2004). However, this type of operating procedure cannot be applied to boreholes used for agriculture and, therefore, these elements cannot be used as tracers. However, under certain conditions, it seems that the As concentrations were only slightly modified during water pumping. The distribution of $\mathrm{Na}$ versus $\mathrm{Ti}$ and of $\mathrm{Ca}$ versus $\mathrm{Ti}$ in the water samples allows differentiating between water sources.

\subsection{Lanthanides, $Y, T h, U$, HFSE}

This group comprises very insoluble species. Only La, Ce, Th and $\mathrm{U}$ concentrations were measured (Table 4a and Table 4b, Fig. 8). These elements did not exhibit a regular pattern with regard to water-rock interaction (Figs. 8a and c). HC38 and 39 (Cuddalore) were richest in $\mathrm{La}$, whereas $\mathrm{HC} 13$ and 24 (Vanur) were richest in U. No correlation with any element was recorded. Lanthanum and Ce showed a slight trend (Fig. 8b), but Th and U were not correlated (Fig. 8d). 


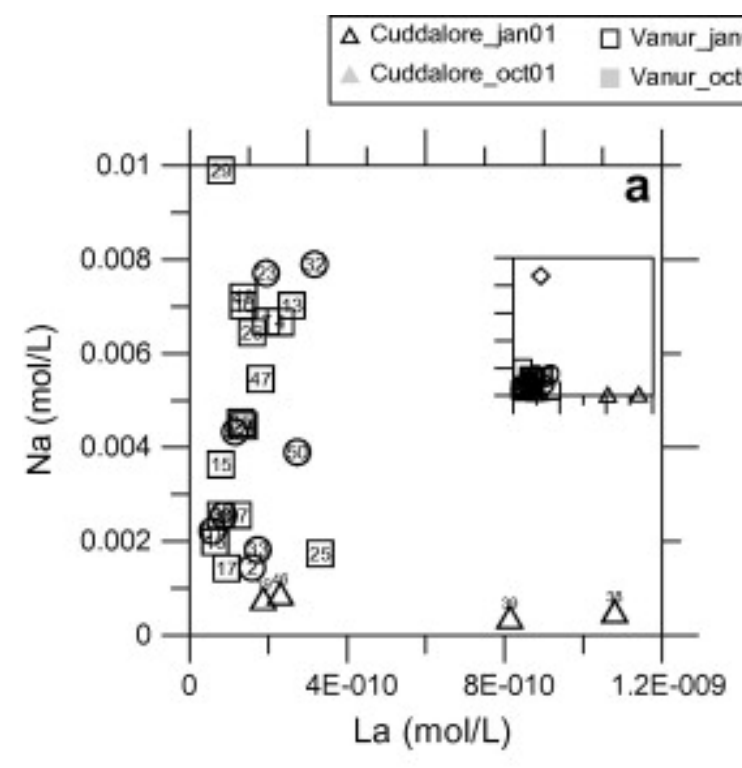

$\diamond$ others_jan01
others_oct01 charnockite_jan01
charnockite_oct01
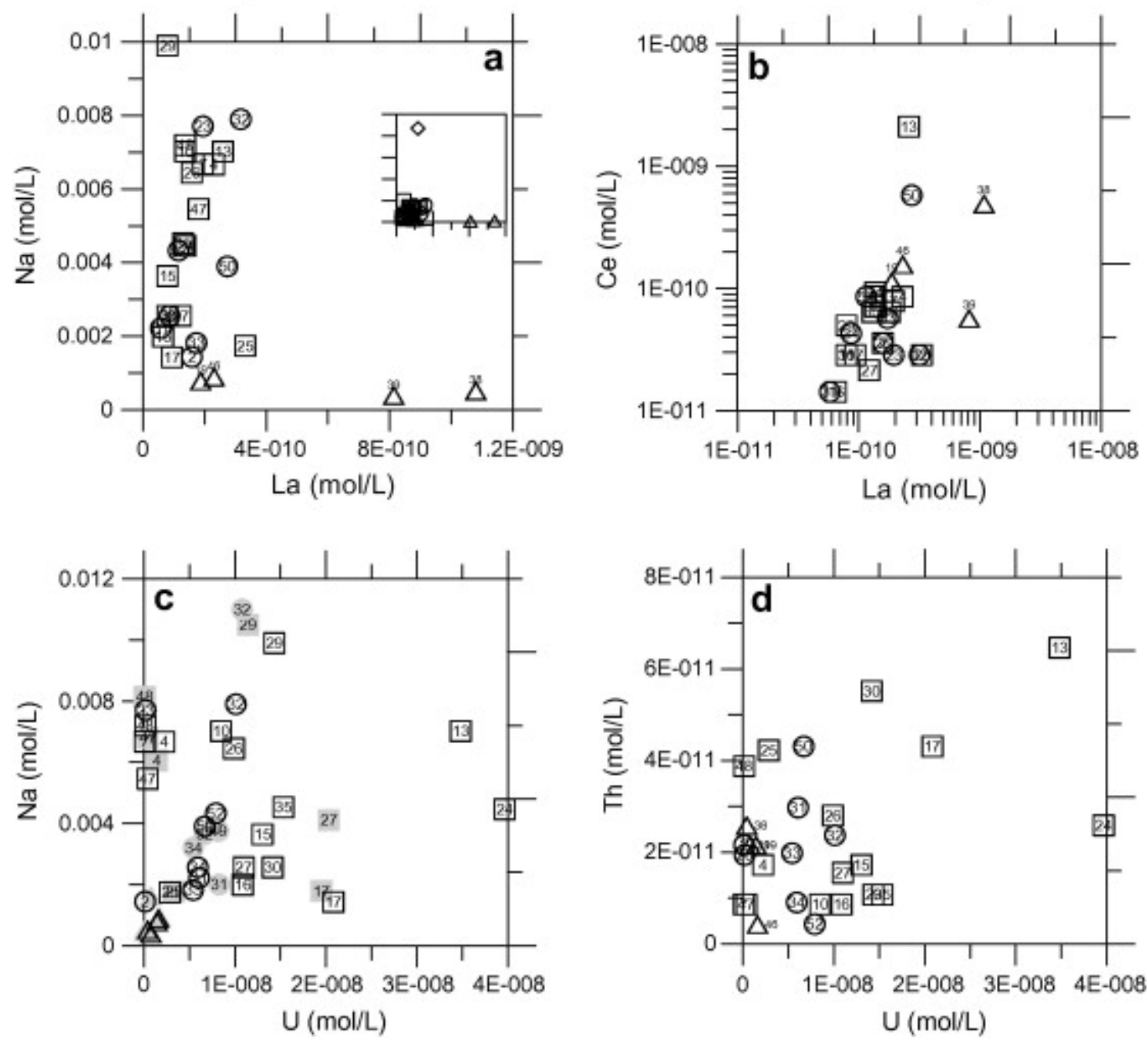

Fig. 8. Distribution of: (a) Na versus La, (b) Ce versus La, (c) Na versus U, and (d) Th versus U in water samples (molar concentrations).

The marked contrast in concentrations observed in rocks was not recorded in waters, and, therefore, these elements cannot be used as fingerprints to identify the aquifer through which the waters flow.

\section{Conclusions}

The results confirm that weathering and lateritization have lead to different trace element contents in sandstone and the parent rock. However, the aquifer formation signature recorded by trace elements is not necessarily observed in the water flowing within it. Three categories of trace elements can be identified: (i) mobile elements, (ii) elements whose solubility depends on the oxidation state, (iii) low-solubility elements.

The first group comprises alkali and alkaline earth elements. In the study, aquifers could be differentiated by $\mathrm{Li}$ and $\mathrm{Ba}$ contents, Li because it originates from different minerals in sandstone (such as micas) and in charnockite (not micas because of the $\mathrm{Li} / \mathrm{Mg}$ ratio), and $\mathrm{Ba}$ because the available stock is greater in charnockite (plagioclase). 
The second group comprises most of the transition elements and $\mathrm{As}, \mathrm{Se}, \mathrm{Pb}$ and $\mathrm{U}$.

Potentially, some of these elements could be used to characterize aquifers, but the difficulty is to preserve Eh conditions during sampling. However, As may preserve the aquifer signature due to its slower oxidation rate.

The third group comprises low-mobility transition elements such as Ti, lanthanides, Y, Th and HFSE. These elements are potentially the most suitable for use as tracers, their main limitation being their very low solubility (with corresponding low concentrations). The only one that could be used in the studied aquifers is Ti. Titanium-bearing minerals which are associated with plagioclases appeared to be less stable than isolated ones, leading to a good correlation between $\mathrm{Ca}$ and $\mathrm{Ti}$ throughout the aquifer. This correlation integrates both available stock (plagioclase) and reaction rate. The Vanur and charnockite aquifers could also be differentiated by $\mathrm{Na}$ due to their different plagioclase contents.

This study showed that trace elements can be used as specific tracers to assess sources of waters and mixing within the aquifer. However, the mineralogical composition of the aquifer formation (trace element-bearing minerals), rate of alteration (for low-solubility species), and specific physico-chemical conditions (e.g. Ti solubility) may restrict their use to aquifers with similar origin or long-residence time groundwater.

\section{Acknowledgements}

This work was supported by UMR-Sisyphe, GéEAC, Harvest AWS (field logistics), NEB (Grant for 1999 survey), and a CNRS-INSU Grant (ACI Eau, 2000-2002). We would like to thank G. de Marsily, T. Gablier, G. Boulicot and S. Violette for their kind support. We are grateful to O. Henin and J. Macé in the Geosciences department in Rennes for their assistance with analysis of $\mathrm{Sr}$ isotope ratio measurements by TIMS.

\section{References}

Achyuthan, $1996 \mathrm{H}$. Achyuthan Geomorphic evolution and genesis of laterites around the east coast of Madras, Tamil Nadu, India Geomorphology, 16 (1996), pp. 71-76

Armstrong et al., 1998 S.C. Armstrong, N.C. Sturchio, M.J. Hendry Strontium isotopic evidence on the chemical evolution of pore waters in the Milk River Aquifer, Alberta, Canada Appl. Geochem., 13 (1998), pp. 463-475

Aubert et al., 2001 D. Aubert, P. Stille, A. Probst REE fractionation during granite weathering and removal by waters and suspended loads: $\mathrm{Sr}$ and $\mathrm{Nd}$ isotopic evidence Geochim. Cosmochim. Acta, 65 (2001), pp. 387-406

Banfield and Eggleton, 1989 J.P. Banfield, R.A. Eggleton Apatite replacement and rare earth mobilization, fractionation, and fixation during weathering Clays Clay Miner., 37 (1989), pp. 113-127

Banks et al., 1999 D. Banks, G. Hall, C. Reimann, U. Siewers Distribution of rare earth elements in crystalline bedrock groundwaters: Oslo and Bergen regions, Norway Appl. Geochem., 14 (1999), pp. 27-39 
Bau et al., 2004 M. Bau, B. Alexander, J.T. Chesley, P. Dulski, S. Brantley Mineral dissolution in the Cape Cod aquifer, Massachusetts, USA: I. Reaction stoichiometry and impact of accessory feldspar and glauconite on strontium isotopes, solute concentrations, and REY distribution Geochim. Cosmochim. Acta, 68 (2004), pp. 11991216

Beaucaire and Michard, 1982 C. Beaucaire, G. Michard Origin of dissolved minor elements (Li, Rb, Sr, Ba) in superficial waters in a granitic area Geochem. J., 16 (1982), pp. 247-258

Bernard-Griffiths et al., 1987 J. Bernard-Griffiths, B.-M. Jahn, S.K. Sen Sm-Nd isotopes and REE geochemistry of Madras granulites, India: an introductory statement Precambrian Res., 37 (1987), pp. 343-355

Bhattacharya, 1996 S. Bhattacharya Eastern Ghats granulite terrain of India: an overview J. Southeast Asian Earth Sci., 14 (1996), pp. 165-174

Bourgeon, $1988 \mathrm{G}$. Bourgeon Esquisse sur les grandes zones de sols du Sud de l'Inde Cahier de l'ORSTOM, Série Pédologie, XXIV (1988), pp. 303-328

Braun et al., 1990 J.-J. Braun, M. Pagel, J.-P. Muller, P. Bilong, A. Michard, B. Guillet Cerium anomalies in lateritic profiles Geochim. Cosmochim. Acta, 54 (1990), pp. 781-795

Brenot et al., 2008 A. Brenot, N. Baran, E. Petelet-Giraud, P. Négrel Interaction between different water bodies in a small catchment area in the Paris basin (France): Sr isotopic tracing of multiple Sr sources Appl. Geochem., 23 (2008), pp. 58-76

Brookins, 1989 D.G. Brookins Aqueous geochemistry of rare earth elements Rev. Mineral., 21 (1989), pp. 201-225

Buffle and De Vitre, 1994 J. Buffle, R.R. De Vitre Chemical and Biological Regulation of Aquatic Systems Lewis Publishers, CRC Press, Inc (1994)

Chiquet et al., 2000 A. Chiquet, F. Colin, B. Hamelin, A. Michard, D. Nahon Chemical mass balance of calcrete genesis on the Toledo granite (Spain) Chem. Geol., 170 (2000), pp. 19-35

Colin et al., 1993 F. Colin, P. Vieillard, J.P. Ambrosi Quantitative approach to physical and chemical gold mobility in equatorial rainforest lateritic environment Earth Planet. Sci. Lett., 114 (1993), pp. 269-285

de Carlo et al., 1997 E.H. de Carlo, X.-Y. Wen, M. Irving The influence of redox reactions on the uptake of dissolved $\mathrm{Ce}$ by suspended $\mathrm{Fe}$ and $\mathrm{Mn}$ oxide particles Aquatic Geochem., 3 (1997), pp. 357-389

equincey et al., 2002 O. Dequincey, F. Chabaux, N. Clauer, O. Sigmarsson, N. Liewig, J.C. Leprun Chemical mobilizations in laterites: evidence from trace elements and ${ }^{238} \mathrm{U}-{ }^{234} \mathrm{U}-$ ${ }^{230}$ Th disequilibria Geochim. Cosmochim. Acta, 66 (2002), pp. 1197-1210

Dhar et al., 2008 R.K. Dhar, Y. Zheng, M. Stute, A. van Geen, Z. Cheng, M. Shanewaz, M. Shamsudduha, M.A. Hoque, M.W. Rahman, K.M. Ahmad Temporal variability of 
groundwater chemistry in shallow and deep aquifers of Araihazr, Bangladesh J. Contam. Hydrol., 99 (2008), pp. 97-111

D'Ozouville et al., 2006 N. D'Ozouville, S. Violette, N. Gassama, A. Dia, N. Jendrzejewski Origin and modelling of water salinization in a coastal aquifer of the Bay of Bengal: the Kaluvelly watershed, Tamil Nadu, India Bull. Soc. Géol. France, 177 (6) (2006), pp. 333345

Dulski, 2001 P. Dulski Reference materials for geochemical studies: new analytical data by ICP-MS and critical discussion of reference values Geostand. Newslett. J. Geostand. Geoanal., 25 (2001), pp. 87-125

Dzombak and Morel, 1990 D.A. Dzombak, F.M.M. Morel Surface Complexation Modelling - Hydrous Ferric Oxide John Wiley, New York (1990)

Eary and Schramke, 1990 Eary, L.E., Schramke, J.A., 1990. Rates of inorganic oxidation reactions involving dissolved oxygen. In: Melchoir, D.C., Bassett, R.L. (Eds.), Chemical Modeling of Aqueous Systems II. American Chemical Society Symp. Series 416, pp. 379396.

Gardner, 1980 L.R. Gardner Mobilization of Al and Ti during weathering - isovolumetric evidences Chem. Geol., 30 (1980), pp. 151-165

Gassama et al., 2011 N. Gassama, A. Dia, S. Violette Origin of salinity in a multilayered aquifer with high salinization vulnerability Hydrol. Process., 1 (2011) http://dx.doi.org.biblioplanets.gate.inist.fr/10.1002/hyp.8125

Gosselin et al., 2004 D.C. Gosselin, F.E. Harvey, C. Frost, R. Stotler, P.A. Macfarlane Strontium isotope geochemistry of groundwater in the central part of the Dakota (Great Plains) aquifer, USA Appl. Geochem., 19 (2004), pp. 359-377

Govindaraju, 1994 K. Govindaraju Compilation of working values and sample description for 383 geostandards Geostand. Newslett., Spec. Iss., XVIII (1994), pp. 1-158

Greenwood and Earnshow, 1997 N.N. Greenwood, A. Earnshow Chemistry of the Elements (second ed.)Butterworth Heinemann, Oxford (1997)

Grenthe et al., 1992 I. Grenthe, W. Stumm, M. Laaksuharju, A.-C. Nilsson, P. Wikberg Redox potentials and redox reactions in deep groundwater systems Chem. Geol., 98 (1992), pp. 131-150

Hodge et al., 1996 V.F. Hodge, K.H. Johannesson, K.J. Stetzenbach Rhenium, molybdenum, and uranium in groundwater from the southern Great Basin, USA: evidence for conservative behavior Geochim. Cosmochim. Acta, 60 (1996), pp. 31973214

Jaya Kumar et al., 1984 Jaya Kumar, B., Chandra, P.C., Veeranjaneyulu, D., Adil, Md., Narayana Raju, V., Tata, S.N., 1984. Hydrological Conditions in Auroville. Government of India, Central Ground Water Board, Ministry of Water Resource, Southern Region, Hyderabad, May 1984, Report. 
Jenne, 1968 Jenne, E.A., 1968. Controls on $\mathrm{Mn}, \mathrm{Fe}, \mathrm{Co}, \mathrm{Ni}, \mathrm{Cu}$ and $\mathrm{Zn}$ concentration in soils and water: the significant role of hydrous $\mathrm{Mn}$ and Fe oxides. In: Gould, R.F. (Ed.), Trace Inorganics in Water. American Chemical Society Advances in Chemistry Series 73, pp. 337-387.

Kaufmann et al., 1993 R.S. Kaufmann, S.K. Frape, R. McNutt, C. Eastoe Chlorine stable isotope distribution of Michigan Basin formation waters Appl. Geochem., 8 (1993), pp. 403-407

Kim and Nriagu, 2000 M.J. Kim, J. Nriagu Oxidation of arsenite in groundwater using ozone and oxygen Sci. Total Environ., 247 (2000), pp. 71-79

Kuhn and Sigg, 1993 A. Kuhn, L. Sigg Arsenic cycling in eutrophic Lake Greifen, Switzerland: influence of seasonal redox processes Limnol. Oceanogr., 38 (1993), pp. 1052-1059

Lavastre et al., 2005 V. Lavastre, N. Jendrzejewski, P. Agrinier, M. Javoy, M. Evrard Chlorine transfer out of a very low permeability clay sequence (Paris Basin, France): ${ }^{35} \mathrm{Cl}$ and ${ }^{37} \mathrm{Cl}$ evidence Geochim. Cosmochim. Acta, 69 (2005), pp. 4949-4961

Lucas-Girot et al., 2007 A. Lucas-Girot, O. Hernandez, H. Oudadesse Re-examination of the structural properties of solid solutions $\mathrm{Sr}_{x} \mathrm{Ca}_{1-x} \mathrm{CO}_{3}$ Mater. Res. Bull., 42 (2007), pp. 1061-1068

Mezger and Cosca, 1999 K. Mezger, M.A. Cosca The thermal history of the Eastern Ghats Belt (India) as revealed by $\mathrm{U}-\mathrm{Pb}$ and ${ }^{40} \mathrm{Ar} /{ }^{39} \mathrm{Ar}$ dating of metamorphic and magmatic minerals: implications for the SWEAT correlation Precambrian Res., 94 (1999), pp. 251271

Ndjigui et al., 2008 P.-D. Ndjigui, P. Bilong, D. Bitom, A. Dia Mobilization and redistribution of major and trace elements in two weathering profiles developed on serpentinites in the Lomié ultramafic complex, South-East Cameroon J. Afr. Earth Sci., 50 (2008), pp. 305-328

Nesbitt et al., 1980 H.W. Nesbitt, G. Markovics, R.C. Price Chemical processes affecting alkalis and alkaline earths during continental weathering Geochim. Cosmochim. Acta, 44 (1980), pp. 1659-1666

Pédrot et al., 2010 M. Pédrot, A. Dia, M. Davranche Dynamic structure of humic substances: rare earth element as a fingerprint J. Colloid Interface Sci., 345 (2010), pp. 206-213

Ponthieu et al., 2006 M. Ponthieu, F. Juillot, T. Hiemstra, W.H. Van Riemsdijk, M.F. Benedetti Metal ion binding to iron oxides Geochim. Cosmochim. Acta, 70 (2006), pp. 2679-2698

Raiber et al., 2009 M. Raiber, J.A. Webb, D.A. Bennetts Strontium isotopes as tracers to delineate aquifer interactions and the influence of rainfall in the basalt plains of southeastern Australia J. Hydrol., 367 (2009), pp. 188-199 
Rickers et al., 2001 K. Rickers, K. Mezger, M.M. Raith Evolution of the Continental Crust in the Proterozoic Eastern Ghats Belt, India and new constraints for Rodinia reconstruction: implications from $\mathrm{Sm}-\mathrm{Nd}, \mathrm{Rb}-\mathrm{Sr}$ and $\mathrm{Pb}-\mathrm{Pb}$ isotopes Precambrian Res., 112 (2001), pp. 183-210

Roy and Fouillac, 2004 S. Roy, A.-M. Fouillac Uncertainties related to sampling and their impact on the chemical analysis of groundwater Trends Anal. Chem., 23 (2004), pp. 185193

Salomons and Forstner, 1984 W. Salomons, V. Forstner Metals in the Hydrocycle Springer-Verlag, Berlin (1984)

Sánchez-Martos et al., 2002 F. Sánchez-Martos, A. Pulido-Bosch, L. Molina-Sánchez, A. Vallejos-Izquierdo Identification of the origin of salinization in groundwater using minor ion (Lower Andarax, Southeast Spain) Sci. Total Environ., 297 (2002), pp. 43-58

Schürch et al., 2004 M. Schürch, W.M. Edmunds, D. Buckley Three-dimensional flow and trace metal mobility in shallow Chalk groundwater, Dorset, United Kingdom J. Hydrol., 292 (2004), pp. 229-248

Sen, 1974 S.K. Sen A review of some geochemical characters of the type area (Pallavaram, India) charnockites J. Geol. Soc. India, 15 (1974), pp. 413-420

Sholkovitz et al., 1992 E.R. Sholkovitz, T.J. Shaw, D.L. Schneider The geochemistry of rare earth elements in the seasonally anoxic water column and porewaters of the Chesapeake Bay Geochim. Cosmochim. Acta, 56 (1992), pp. 3389-3402

Stetzenbach et al., 2001 K.J. Stetzenbach, V.F. Hodge, C. Guo, I.M. Franham, K.H. Johannesson Geochemical and statistical evidence of deep carbonate groundwater within overlying volcanic rock aquifer/aquitards of southern Nevada, USA J. Hydrol., 243 (2001), pp. 254-271

Stumm and Morgan, 1970 W. Stumm, J.J. Morgan Aquatic Chemistry: An Introduction Emphasizing Chemical Equilibria in Natural Waters Wiley-Interscience (1970)

Tang et al., 2008 J. Tang, S.J. Köhler, M. Dietzel $\mathrm{Sr}^{2+} / \mathrm{Ca}^{2+}$ and ${ }^{44} \mathrm{Ca} /{ }^{40} \mathrm{Ca}$ fractionation during inorganic calcite formation: I. Sr incorporation Geochim. Cosmochim. Acta, 72 (2008), pp. 3718-3732

Teng et al., 2008 F.-Z. Teng, R.L. Rudnick, W.F. McDonough, S. Gao, P.B. Tomascak, Y. Liu Lithium isotopic composition and concentration of the deep continental crust Chem. Geol., 255 (2008), pp. 47-59

Valeton et al., 1997 I. Valeton, A. Schumann, R. Vinx, M. Wieneke Supergene alteration since the upper cretaceous on alkaline igneous and metasomatic rocks of the Poços de caldas ring complex, Minas Gerais, Brazil Appl. Geochem., 12 (1997), pp. 133-154

Vengosh et al., 1999 A. Vengosh, A.J. Spivack, Y. Artzi, A. Ayalon Geochemical and boron, strontium, and oxygen isotopic constraints on the origin of the salinity in groundwater from the Mediterranean coast of Israel Water Resour. Res., 35 (1999), pp. 1877-1894 
Vinson et al., 2011 D.S. Vinson, J.C. McIntosh, G.S. Dwyer, A. Vengosh Arsenic and other oxyanion-forming trace elements in an alluvial basin aquifer: Evaluating sources and mobilization by isotopic tracers (Sr, B, S, O, H, Ra) Appl. Geochem., 26 (2011), pp. 13641376

Weaver et al., 1978 B.L. Weaver, J. Tarney, B.F. Windley, E.B. Sugavanam, V. Venkata Rao Madras granulites: geochemistry and P.T. conditions of crystallization B.F. Windley, S.M. Naqvi (Eds.), Developments in Precambrian Geology 1: Archaean Geochemistry, Elsevier, Amsterdam (1978), pp. 177-204

Yeghicheyan et al., 2001 D. Yeghicheyan, J. Carignan, M. Valladon, M.B. Coz, F.L. Cornec, M. Castrec-Rouelle, M. Robert, L. Aquilina, E. Aubry, C. Churlaud, A. Dia, S. Deberdt, B. Dupré, R. Freydier, G. Gruau, O. Henin, A.-M. Kersabiec, J. Macé, L. Marin, N. Morin, P. Petitjean, E. Serrat A compilation of silicon and thirty one trace elements measured in the natural river water reference material SLRS-4 (NRC-CNRC) 